\title{
Potential roles of export orientation of Cambodia's agriculture and agro-industry: an application of CGE analysis
}

\author{
Sryneath Chhuor ${ }^{*}$ (D)
}

\section{*Correspondence:}

chhuor.sryneath@gmail.com;

chhuor.sryneath@h.mbox.

nagoya-u.ac.jp

Graduate School

of International

Development,

Nagoya University,

Furo-cho, Chikusa-ku,

Nagoya 464-8601, Japan

\begin{abstract}
For a more diversified export structure and a better distribution of domestic income in Cambodia, agriculture and agro-industry have been specified as export potentials. While empirical impact studies within those sectors have been limited, this paper attempts to assess the impacts of the promising export sectors on domestic economy by applying a computable general equilibrium framework. Results show that the increase in export demand for the selected sectors-food-beverage-tobacco, rubber industry, and agriculture - generate favorably on growth, employment, and household welfare, with the contributions of the former two higher than that of the latter, suggesting that priority should be given to agro-processing exports to increase production chain. The findings indicate that in order for the trading sectors to expand the benefits, productivity growth of low-skilled and medium-skilled labor is crucial. The influence of the selected sectors would be greater when the demand disturbance is combined with supply-side efficiency measure to promote the export orientation.
\end{abstract}

Keywords: Export orientation, Potential export sectors, Computable general equilibrium model, External shocks, Productivity

\section{Background}

Emphasis has been given to export-led growth as a driving force for development as export plays crucial roles in generating income and employment in the domestic economy, as well as in bringing investment, technical upgrade, and industrialization. However, given different characteristics of specific economies, the size of impacts and the effectiveness of policies depend greatly on which sectors the countries rely for export. As for the case of Cambodia, the slow progress of diversification and low value-added content of the current exports make the country vulnerable to shocks and unable to widely contribute to the domestic economy. Five main products account for more than $60 \%$, with articles of apparel alone sharing more than half, of total export in 2012, remaining unchanged from 2000, indicating that diversification toward new products in the recent years has made slow progress (UNCTAD 2014). Moreover, the country is not able to retain value added in its main manufacturing-garment, footwear, and bicycle-as little of the value chains operate inside the country, where intermediate parts are imported and assembled into finished products which are then exported. Despite an

(c) The Author(s) 2017. This article is distributed under the terms of the Creative Commons Attribution 4.0 International License (http://creativecommons.org/licenses/by/4.0/), which permits unrestricted use, distribution, and reproduction in any medium, provided you give appropriate credit to the original author(s) and the source, provide a link to the Creative Commons license, and indicate if changes were made. 
impressive growth of manufacturing export, at an average annual rate of $15 \%$ from 2000 to 2009, Cambodia manufacturing value added per capita remained among the lowest in the region and lagged behind its neighbors such as Vietnam, Thailand, and Indonesia (UNIDO 2011).

Given the narrow-based industrial structure, this country has been depending too high on intermediate textile imports while ignoring the possible benefits of the agricultural endowment to create the connection between agriculture and industrial sector. Hang Chuon (2011) stated that economic growth during the last decade has centered on a few urban-based sectors such as tourism and construction in addition to the garment, while creating more opportunities for trading, investment, and private sector development for urban rather than rural areas. This differentiated growth performance, as a consequence, has widened income and inequality gap between the two regions (Hang Chuon 2011). In response to this issue, previous studies have suggested that agriculture and agro-industry can take part in export-development linkages. Kobayashi et al. (2009), for instance, found that for a better income distribution purpose, Cambodia should give more attention to promoting export of agro-related industries, particularly food manufacturing. Consistently, agriculture, food, and rubber industry have been specified as key sectors promising for export as they are highly linkage-oriented, able to induce high multiplier on income, and possess high labor contents, while garment is unlikely to contribute profit due to the lack of inter-industrial linkages (Chhuor 2016). The government has also recognized the importance of these sectors and has set in the Industrial Development Plan for 2015-2025 to achieve an increase in agro-industrial exports (RGC 2015). ${ }^{1}$ Potential export sectors have been identified; however, their expected impacts on the economy are ambiguous; there is a lack of impact studies and more critical policies with regard to those sectors.

This study, therefore, attempts to assess the impacts on economic factors including growth, employment, and household welfare of three main selected sectors: food-beverage-tobacco industry and rubber industry (classified as agro-industry), and agriculture, which are deemed promising for export-orientated structure of Cambodia. A standard computable general equilibrium (CGE) framework is applied to quantify the economic effects, specifically on growth, investment, sectoral output and employment, government and labor income, household welfare and their interactions. Section 2 discusses the current performance, potential, and remaining challenges of the three selected export sectors, while Sect. 3 briefly reviews previous literature. An introduction to the CGE model characteristics and the data applied in the study are given in Sect. 4. Section 5 describes simulation designs, followed by the discussion of the results, and the last section concludes the paper.

\section{Economic and export performance of agriculture, food, and rubber industry}

The share of agriculture output in GDP reduced from 44\% in 1995 to 23\% in 2014, replaced by industry which doubled to $31 \%$, while the share of service has remained relatively stable during the period (National Institute of Statistics 2015). Despite the decreasing share,

\footnotetext{
${ }^{1}$ The targeted shares of processed agro-export and other products are listed in "Appendix 1."
} 
agriculture activities have played significant roles in contribution to employment and livelihood of more than $70 \%$ of total population, to poverty reduction in rural areas, to food security and equitable economic growth (Hang Chuon 2011). Agro-industry-food and rubber, in this study-should undergo some degrees of preserving, processing, or packaging before distributing to final markets, and are categorized as industrial products, according to Ministry of Industry (National Institute of Statistics 2015).

\subsection{Agriculture}

Agriculture production, a pro-poor sector, has experienced exceptional growth driven by crop production, mainly paddy. Although value-added share in GDP has decreased, agriculture has maintained an average of 5\% growth until 2010 and $2.3 \%$ during the next 4 years. Exports of agricultural products achieved 26\% growth on average from 2000, as shown in Table 1 (UN Comtrade 2016). Nevertheless, the figure can be underestimated due to informal exports crossing the borders to Thailand and Vietnam which have the capacity to process and re-export to third countries (Ministry of Commerce 2014). Rice crops are the main agricultural production and continue to contribute about $10 \%$ of total real growth during 2010-2012. Dry seasonal rice production increased from $18.5 \%$ in 2003 to $23.3 \%$ in 2012, due to more access to irrigation systems. Rice crops depend up to $80 \%$ on expanding cultivated areas, while only $20 \%$ on yield. However, expanding more cultivated areas has decreased due to land area constraints. Rice surplus is estimated at 4.7 million tons in 2012, most of which was exported unprocessed and unrecorded given weak capacity and financing in rice milling (World Bank 2013).

Domestic support was granted for agricultural products at Riel8625 million and Riel10,000 million in 2007 and 2008, respectively (approximate exchange rate US\$1 = Riel4000). Over half of the total support took the form of natural disaster reliefs and the remaining went to pest and disease control, extension and advisory services, training, research, and inspection services (WTO Secretariat 2011). Cambodia Trade Integration Study (CTIS) (MoC 2014) has acknowledged that to enhance benefits of current agricultural products, aiming at increased flow of agricultural exports through formal channel, priorities should be given to two avenues: undertaking some

Table 1 Agriculture export by categories (2000-2014). Source: UN Comtrade (2016), compiled by Author

\begin{tabular}{lllll}
\hline Product categories & $\mathbf{2 0 0 0}$ & $\mathbf{2 0 0 5}$ & $\mathbf{2 0 1 0}$ & $\mathbf{2 0 1 4}$ \\
\hline Total agriculture exports (US\$, thousand) & 5270 & 6659 & 7662 & 35,441 \\
Share in total exports (\%) & 0.4 & 0.2 & 0.1 & 0.3 \\
Share in agri. exports by categories (\%) & & & & \\
Crops & 5.2 & 28.9 & 38.4 & 6.3 \\
Pepper and other spices & 0.0 & 0.7 & 1.4 & 21.1 \\
Live animals & 0.9 & 0.2 & 1.3 & 0.2 \\
Fisheries & 75.4 & 15.4 & 10.8 & 1.7 \\
Forestry and logging & 0.0 & 1.0 & 7.9 & 0.0 \\
Vegetables and fruit & 0.9 & 2.9 & 5.9 & 66.0 \\
Oil seeds and oleaginous fruits & 10.6 & 38.9 & 29.3 & 3.7 \\
Other animal and vegetable materials & 6.9 & 12.0 & 4.9 & 1.1 \\
Total & 100.0 & 100.0 & 100.0 & 100.0 \\
\hline
\end{tabular}


degree of processing inside the country, and increasing direct export to final markets. These should require mechanism to execute government's strategy effectively. Reduction of informal domestic payments during transport and export procedure should also be deemed vital. Moreover, although with increasing values, agriculture has experienced slower growth in the last few years, explained by depressed agricultural commodity price and slow yield improvements after 2013 (World Bank 2015). Rice production and yield of the wet season decreased by 2.5 and 3\%, respectively, in 2014 from the past year. While production growth had depended to a large extent on cultivated area expansion, current land constraints have become a concern. Agricultural output growth should from now on depend on yield improvements rather than land expansion.

\subsection{Food, beverage, and tobacco}

The sector achieved 5\% growth on average from 2005 and shared 9\% in total manufacturing output in 2014. Exports remain low, but the values have increased fourfold from 2010 to 2014, accounting for 3\% of total exports (UN Comtrade 2016). Table 2 lists the share of main export items which are milled rice, tobacco, sugar preparation, and animal and vegetable oil. Milled rice surplus has increased gradually from 2000 as a result of paddy production, at a 9\% annual growth (WTO 2011). Milled rice exports, with a $28 \%$ increase year on year reaching 185 thousand metric tons during the first 6 months of 2013, have benefited from Everything-but-Arms initiative under the preferences of EU market, the main export partner (World Bank 2013). To improve trading of rice sector, the government in 2010 has set the year 2015 as the target year to achieve [formal] exports of milled rice of at least one million tons and to ensure the international recognition of Cambodian rice (RGC 2010). Productivity enhancement and commercialization are essential tools to achieve this target, whereas public and private financing has moved to agriculture and agriculture processing activities. Unfortunately, total milled

Table 2 Food-beverage-tobacco export by categories (2000-2014). Source: UN Comtrade (2016), compiled by Author

\begin{tabular}{|c|c|c|c|c|}
\hline Product categories & 2000 & 2005 & 2010 & 2014 \\
\hline Total agro-food exports (US\$, thousand) & 8482 & 22,130 & 76,201 & 326,908 \\
\hline Share in total exports (\%) & 0.6 & 0.7 & 1.4 & 3.1 \\
\hline \multicolumn{5}{|l|}{ Share in agro-food exports by categories (\%) } \\
\hline Meat and meat preparations & 0.0 & 0.8 & 0.0 & 0.0 \\
\hline Dairy products & 31.8 & 0.0 & 0.0 & 0.0 \\
\hline Fish products & 23.8 & 41.1 & 2.6 & 0.0 \\
\hline Cereal preparations (exclude rice) & 0.4 & 0.3 & 0.3 & 0.1 \\
\hline Rice (milled, husked) & 10.3 & 13.5 & 45.6 & 70.8 \\
\hline Vegetables and fruit & 3.5 & 4.3 & 0.8 & 0.3 \\
\hline Sugars and sugar preparations & 0.0 & 0.1 & 6.8 & 10.7 \\
\hline Coffee, tea, cocoa, spices & 0.0 & 0.0 & 0.0 & 0.0 \\
\hline Animal and vegetable oils and fats & 0.0 & 3.5 & 13.2 & 4.9 \\
\hline Other animal and vegetable materials & 0.1 & 0.0 & 0.0 & 0.1 \\
\hline Other food items & 0.7 & 4.3 & 10.7 & 5.2 \\
\hline Beverage & 3.9 & 3.7 & 4.9 & 2.5 \\
\hline Tobacco & 25.5 & 28.4 & 15.2 & 5.4 \\
\hline Total & 100.0 & 100.0 & 100.0 & 100.0 \\
\hline
\end{tabular}




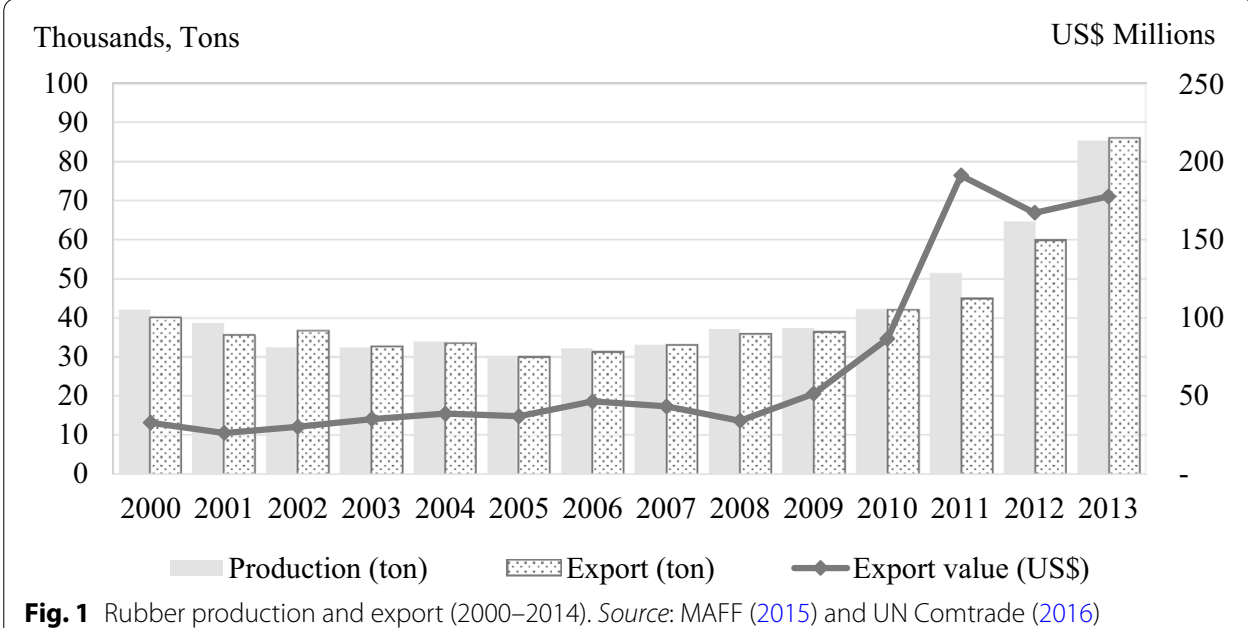

rice exports in 2015 were almost 50\% behind the target, which could be explained by the limited milling and financing capacity.

Industrial development plan of the government of Cambodia also targets an increase of agro-industrial exports from $8 \%$ in 2015 to $12 \%$ in 2025 (RGC 2015). With agricultural endowment and significant changes underway global demand for ready-made food products in Asia, Cambodia has an opportunity to expand its processed food production and exports. However, the number of items exported has been limited, while milled rice and beer are the only two goods listed as potential exports in the DTIS (MoC 2007); ${ }^{2}$ Cambodia should be able to enlarge further its exporting items of this sector. Despite its potential, agro-food industry-other than milled rice sector-has received little strategic attention, with the lack of investment along the value chain. Also, CTIS (MoC 2014) reported that national business association specific to this industry has yet to exist in Cambodia, which limits the open discussion between public and private sectors. Moreover, Agro-food industry is characterized mostly by small and medium enterprises (SMEs), with emerging large firms, depending extensively on domestic demand, while at an early stage breaking into the international market, whereas the lack of compliance with quality standard of sanitary and phyto-sanitary (SPS) measures at the top level of output is a key constraint. With the challenges, encouraging investment and value addition, and improving the quality standards should be a priority.

\subsection{Rubber}

Rubber plantation has soared significantly from 2007 and covered 328,771 ha in 2013, comprising of $17 \%$ of rubber estates (former state-owned enterprises), $41 \%$ of economic land concession, and another $42 \%$ of household rubber plantation (Ministry of Agriculture, Forestry and Fisheries (MAFF) 2015). Figure 1 illustrates that the sector yielded 85,244 tons of dry rubber, with 86,052 tons of exports in 2013, almost all of which are in the form of natural rubber ${ }^{3}$ (MAFF 2015; Ministry of Commerce 2014). In total, 87\% of

\footnotetext{
${ }^{2}$ List of the 19 potential products and services is given in "Appendix 2."

3 The figure may be underestimated due to significant quantities of natural rubber exported informally across borders (MoC 2014).
} 
formal natural rubber exports in 2007 went to Vietnam which had suitable facility to process and re-export. Over the past 5 years, however, the figure has declined to $58 \%$ as exports to other markets, notably China and Malaysia, have grown due to significant investment efforts and expansion of the production capacity. Although current rubber production is in small scale, it can be seen as a long-term streamlining agro-industrial sector, as it is basically non-heavy manufacturing with inputs and labors that can be supplied locally. Notwithstanding, the remaining challenges, not different from that of other agro-products, are the difficulties in meeting international standards. Some other constraints include high input and utility cost, limited finance and cash flow among producers and processors, relatively low yield, excessive paperwork required for export, and low custom clearance efficiency (WTO 2011).

\section{Literature reviews}

Roles of export have been examined using different measures such as the treatment of export as a factor of production in econometric model, the qualitative discussion, and the computable general equilibrium (CGE) model (Ram 1985; Tyler 1981; Balassa 1978; Ganuza et al. 2005). The reviews of the potential impacts of sectoral export from previous studies, therefore, should be divided into two parts: the non-CGE model (both qualitative and empirical studies) and the CGE models. For the former, Tyler (1981) studied a cross-country analysis from 1960 to 1977 by including export as a factor input and found a strong association between output growth and manufacturing exports in developing economies. For Cambodia's case, CTIS (Ministry of Commerce 2007) suggested a list of 19 potential exports, of which garment and footwear rank high and medium, respectively, in human development assessment, based on their previous performance, while most of agricultural products rank from low to medium. Nonetheless, the indicator could not quantify the prospect impacts of those sectors. A firm-level survey, on the other hand, was conducted with 164 sample garment companies to observe the roles of this export industry (Yamagata 2006). The results confirmed that the industry has contributed substantially to poverty reduction through job creations and wages and, however, suggested that with the fast development led by labor-intensive industry, the government has lacked a strong industrial promotion policy.

For the empirical literature, Chan and Oum (2011) studied the impacts of garment and textile trade preferences on livelihoods in Cambodia by applying input-output model. Similar to the above study, they found that the garment industry has contributed to above $9 \%$ on average of GDP growth between 1998 and 2008 and has helped reduce poverty due to a large employment of rural labor. However, the paper concluded that despite its expansion, the industry has not contributed to improve labor productivity and not likely to sustain in the medium to long term due to the tough competition with other garment-exporting countries. Similarly, applying the model of input-output framework, yet rather than focusing on only garment, Kobayashi et al. (2009) studied industrial structure of Cambodia and the role of agriculture by estimating sectoral gross output and value added. They found that agriculture and food sector had a tendency to induce high and wide distribution of income; nevertheless, the focus on export impacts of those sectors has not been emphasized. 
Different measures can examine the impacts of export sectors as discussed in the above literature; however, by which channels the contribution may go through is not explicitly identified. CGE approach, therefore, has been introduced as an alternative method for country-focus studies since this approach is able to capture the full effects on both macro- and micro-level-changes at economy-wide to resulting impacts on distribution of income (Ganuza et al. 2005). Studies of different Latin American countries-Costa Rica, Bolivia, and Cuba-have been carried out to examine macroeconomic performance along with export performance, how economic reform effects export and vice versa, by dividing export products into a few main different groups, in which both macroeconomic effects and policy alternatives are explored by the counterfactual analysis (Ferriol et al. 2006; Jiménez 2007; Sánchez and Sauma 2006). The study of Costa Rica by Sánchez and Sauma (2006), for example, showed that the growth during the previous decade is explained mainly by the increase in exports, especially non-traditional trade; however, the results of the simulations revealed that impacts of current economic process, including the performance of exports, on poverty reduction and income distribution are ambiguous (reduced poverty but also increased inequality). Meanwhile, Cuba's case captured the supply side by taking into account government's active role in macroeconomic management and revealed that economic activity is more constrained by supply than demand (Ferriol et al. 2006). Therefore, the need to increase supply, either quantity or efficiency, should be important to realize full benefits from the increase in demand.

Other studies took into account the impact of specific sectors. Banse et al. (2007) assessed the impact of FDI, measured by technology/productivity growth, on food industry in European region, applying regional CGE model. The food industrial harmonization and technological changes resulted in a limited impact on macroeconomic factors as a whole, yet produced a favorable impacts on agri-food development, in general, such as an increase in production and trade, and an improved productivity and market integration of this sector, and on agriculture income, in particular. In a broader sense in modeling the development process of (1) agriculture, (2) agriculture-development-led industrialization (ADLI), and (3) primary sector export-oriented strategy of Mozambican economy, Tarp and Tarp (2004) ran experiments to see how productivity and marketing margin impacted the three strategies. The result revealed that agricultural development benefited both agricultural and non-agricultural households, but did not reduce poverty, while more income/welfare reached the rural poor in ADLI scenario. The last strategy, on the other hand, achieved pro-equity with limited impacts on economy for short to medium term since the export of primary sector is a minority.

Kobayashi et al. (2008) studied the economic structure and poverty reduction of Cambodia based on CGE model and suggested that the difference in growth rate between fishery and service sectors is one cause of the income conflict among groups, while agricultural and food exports induce growth with better income distribution. Meanwhile, their simulation results also revealed that for a more efficient pro-poor growth in Cambodia, preferential treatment for food manufacture and textile (categorized as light industries) is preferable. While the study discussed the economic structure as a whole, export structure and promotion policy of strategic export sectors were not focalized in their experiments. 
With limited number of empirical export impact studies in Cambodia's case, most of which take into account garment sector, the focus on agriculture, food, and rubber sector has been few despite the recognition of their potential distribution. To fill this gap, the current study aims at analyzing the export potential roles of these three sectors: food and rubber as agro-industrial sectors, and agriculture by employing CGE model, taking into consideration the impacts on growth, employment, production, and household income.

\section{Methods and data}

\subsection{The CGE model}

CGE models are used extensively in policy analysis as they capture linkages at different levels, including sectoral level of production structure and trade, factor level of employment of labor and capital, household level of income and consumption, as well as economy-wide changes or shocks (Hosoe et al. 2010; Vos 2007). Producers and consumers interact through product and factor markets, buying and selling goods and services. The CGE model applied in the study is based on the standard one-country one-period 1-1 model of the Partnership for Economic Policy (PEP), developed by Ducaluwe et al. (2013). The model captures the production and market activities through specific nested structure sketched in Fig. 2.

\subsubsection{Production}

At the top level of output, production technology follows Leontief production function between different intermediates and between intermediate and production factors. Each industry combines value-added and intermediate inputs in fixed shares, strictly complementary, without substitutability, following Leontief production function. At the second level, value-added bundle consists of composite labor and capital, which are imperfect substitutable, following constant elasticity of substitution (CES) specification as in the equation below,

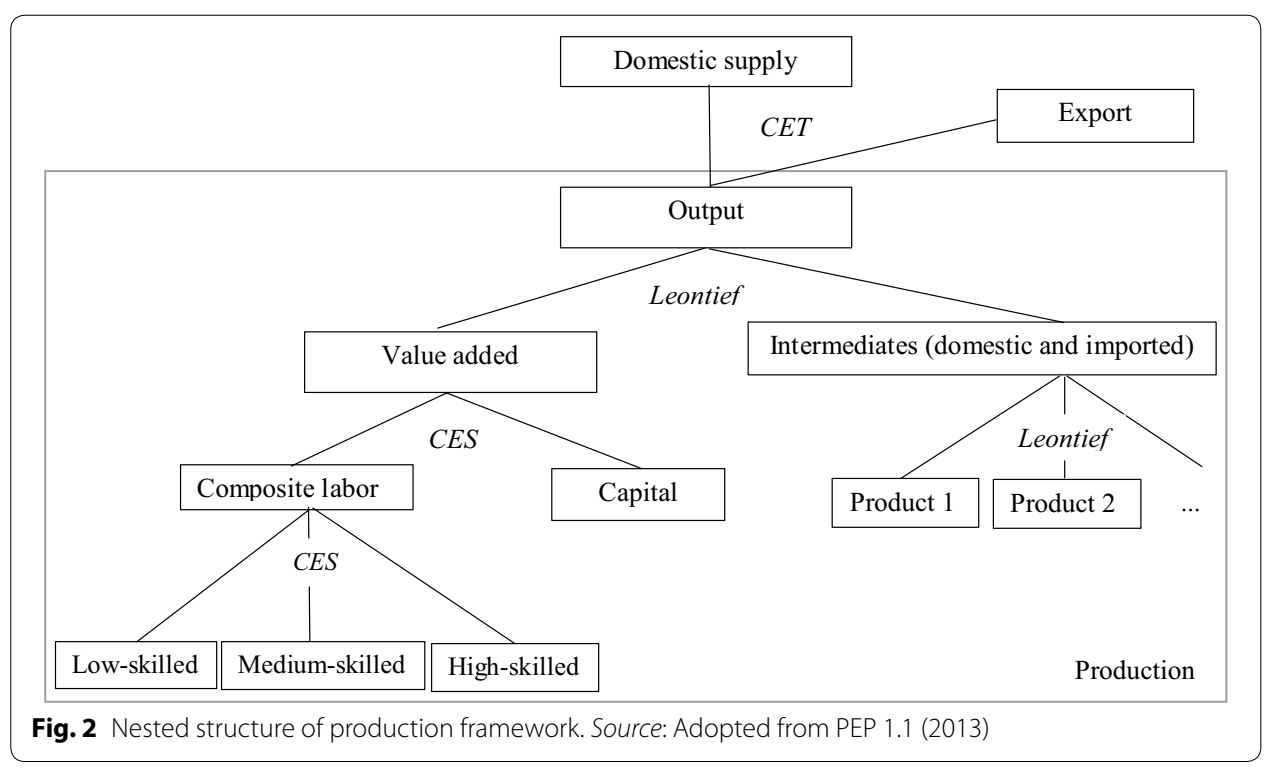




$$
V A_{j}=B_{j}^{V A}\left[\beta_{j}^{V A} L D C_{j}^{-\rho_{j}^{V A}}+\left(1-\beta_{j}^{V A}\right) K D C_{j}^{-\rho_{j}^{V A}}\right]^{-\frac{1}{\rho_{j}^{V A}}}
$$

where $j$ represents each industry, VA is value added, LDC and KDC are demand for composite labor and capital, and $B^{\mathrm{VA}}, \beta^{\mathrm{VA}}$, and $\rho^{\mathrm{VA}}$ are scale, share, and elasticity parameter of CES value added.

Composite labor also follows CES function. Producers are assumed to operate in a competitive environment, so they follow profit maximization function subject to production technology which describes how industries use inputs to produce aggregate outputs. Firms will employ labor and capital to the point where the value marginal product of each is equal to its price (wage rate for labor and rental rate for capital). Such function is described by the demand for labor relative to the demand for capital. Similarly, given imperfect substitutability between different types of labor, the firms minimize labor costs by choosing their labor composition in response to relative wage rates. For the intermediate input side, intermediate consumption is made up of domestic and imported goods and services and assumed to be perfectly complementary, following Leontief production specification.

\subsubsection{Supplies of products and international trade}

The supplies of production outputs are distributed into domestic and foreign markets through constant elasticity of transformation (CET) function (tradable goods). First, producers decide the amount of output among different products based on revenue maximization hypothesis, given product prices. Second, the output is shared out among markets, either domestic or export, again to maximize sale revenues, in response to demand in each market and taxes imposed, as in Eq. (2),

$$
X S_{j, i}=B_{j, i}^{X}\left[\beta_{j, i}^{X} E X_{j, i}^{\rho_{j, i}^{X}}+\left(1-\beta_{j, i}^{X}\right) D S_{j, i}^{\rho_{j, i}^{X}}\right]^{\frac{1}{\rho_{j, i}}}
$$

where XS is industry $j$ production of commodity $i$, DS is supply of commodity $i$ to the domestic market, EX is export supply to foreign market, and $B^{X}, \beta^{X}$, and $\rho^{X}$ are scale, share, and elasticity parameter of CET between export and local sales.

Trade-focused CGE specifies export supply as CET function, as it assumes that although industries can reorganize production to change the proportion of goods between export and domestic sales (DS), the products for different markets are not perfectly transformable, and thus, the CET function describes how the proportion can be adjusted based on price changes (export price, PE, and local price, PL) of commodity $i$, as depicted in export supply Eq. (3) $\left(\mathrm{EX}_{j, i}\right)$. As for the export demand [Eq. (4): $\mathrm{EXD}_{i}$ ], the model adopts the small-country hypothesis which infers that world export and import prices are exogenous. In spite of this, the model assumes that producers cannot always sell as much as they want on the world market; instead, domestic producers can increase their share of the world market only by offering a f.o.b price $\left(\mathrm{PE}_{i}^{\mathrm{FOB}}\right)$ that is advantageous relative to the world export price $\left(\mathrm{PWX}_{i}\right)$. To what extend the share can be increased depends on the degree of substitutability of the specific product (price elasticity of export demand $\sigma_{i}^{\mathrm{XD}}$ ). Export supply and export demand are depicted in equations below. 


$$
\begin{aligned}
& E X_{j, i}=\left[\frac{1-\beta_{j, i}^{X}}{\beta_{j, i}^{X}} \frac{P E_{i}}{P L_{i}}\right]^{\sigma_{j, i}^{X}} D S_{j, i} \\
& E X D_{i}=E X D_{i}^{O}\left[\frac{e P W X_{i}}{P E_{i}^{F O B}}\right]^{\sigma_{i}^{X D}}
\end{aligned}
$$

The model also assumes imperfect substitutability between imported and domestically produced goods, differentiated by origins, which specifies import demand following Armington function (Ducaluwe et al. 2013; Ganuza et al. 2005). In other words, the imperfect substitutability between import demand [shown in Eq. (5), $\mathrm{IM}_{i}$ ] and demand for domestic goods $(\mathrm{DD} i)$ is represented by CES $\left(\sigma_{i}^{M}\right)$. The PEP model assumes the price elasticity of import supply is infinite at the going world price, implying by the exogenous world import price.

$$
I M_{i}=\left[\frac{\beta_{i}^{M}}{1-\beta_{i}^{M}} \frac{P D_{i}}{P M_{i}}\right]^{\sigma_{i}^{M}} D D_{i}
$$

\subsubsection{Income and savings}

Household income, $\mathrm{YH}_{h}=\mathrm{YH} l_{h}+\mathrm{YHK}_{h}+\mathrm{YHTR}_{h}$, comes from labor income $\left(\mathrm{YH} l_{h}\right)$ and capital income $\left(\mathrm{YHK}_{h}\right)$, as factor payment, and transfers from other agents $\left(\mathrm{YHTR}_{h}\right)$. After paying taxes, transferring to government, and savings, disposable income is entirely dedicated as consumption. Household savings are a linear function of disposable income, and consumption demand follows a linear expenditure system for utility maximization subject to income.

Government income is described by YG $=$ TDHT + TPRODN + TPRCTS + YGK + YGTR. Government collects taxes as a source of revenues, such as income taxes (TDHT), production taxes (TPRODN), and taxes on products, imports, and exports (TPRCTS), provided that the PEP-1-1 model takes into account a variety of tax instruments. In addition, government receives transfers from other agents (YGTR) and remuneration of capital (YGK). Similar to household savings, income taxes are considered as a linear function of total income. The model also distinguishes tax rates by industry and by type of labor and capital. On the other hand, government expenditures consist of transfer payments to other agents and current expenditure on goods and services. The difference between its revenues and its expenditures is the current government budget, which can be surplus or deficit (positive or negative savings).

Rest of the world: The rest of the world, the last agent in the model, ${ }^{4}$ receives income from import payment, capital income, and transfers from domestic agents, while making foreign spending to the domestic economy through the values of exports and transfers to domestic agents. The amount of rest of the world savings is the difference between foreign receipts and spending, which are exactly equal to the current account balance of domestic economy but of opposite sign (SROW $=-\mathrm{CAB})$.

\footnotetext{
${ }^{4}$ Business is another agent in the PEP-1-1 model, but it is not characterized in the current study.
} 
Transfers: Household transfers to government are usually treated as contributions to social programs, so they are treated in the same way as income taxes. Meanwhile, transfers from household to non-government agents are proportional to disposable income. It should be noted that transfers are not explicitly associated with a specific form of economic behavior in CGE model due to the lack of precise information of the transactions, so they should be treated in the most neutral way possible to prevent them influencing economic activities.

\subsubsection{Demand}

Demand consists of intermediate demand, household consumption, investment demand, public sector demand, and demand as transport and trade margins, all of which cover domestic and imported goods and services.

Household consumption $\left(C_{i . h}\right)$ is determined by utility maximization subject to income, which is specified by

$$
P C_{i} C_{i, h}=P C_{i} C_{i, h}^{M I N}+\gamma_{i, h}^{L E S}\left(C T H_{h}-\sum_{i j} P C_{i j} C_{i j, h}^{M I N}\right)
$$

This type of demand follows a linear expenditure system (Stone-Geary utility functions) which assumes a minimum level of consumption of each commodity $\left(C_{i, h}^{\mathrm{MIN}}\right)$ (can be zero for some commodities), given marginal share $\left(\gamma_{i, h}^{\mathrm{LES}}\right)$ of each commodity in consumption budget $\left(\mathrm{CTH}_{h}\right)$. Since this assumption imposes neither zero cross-price elasticity nor unit income elasticity for all goods, it offers a flexibility of substitution in response to relative price changes.

Demand for investment includes gross fixed capital formation (GFCF) and inventory changes. The former is always positive and endogenous in this PEP model, while the latter can be either positive or negative in the SAM and is usually treated as exogenous in CGE models. Total investment expenditure is characterized by savings-investment equilibrium, with savings endogenous. GFCF equals to the difference between total investment expenditure and the cost of inventory changes and is distributed in fixed shares among commodities, given by Cobb-Douglas production function. Therefore, the investment demand for each commodity is negatively associated with its purchaser price.

Government consumption on goods and services follows the same hypothesis in the way that, given current expenditure budget, quantity demand for each commodity is distributed in fixed shares and varies inversely related to its price.

Margin rates are applied to the volume of domestic production and imports which require transport and trade services. The amount determines margin services required to move and distribute commodities to the market. Finally, in addition to the final demand, goods and services are used as intermediate inputs in the production. Intermediate demand for each commodity is the sum of industry demands.

\subsubsection{Price}

Price of production: In principle, the price of an aggregate is a weighted sum of the prices of its components, in which the weights are determined by equating the value of the aggregate to the sum of the values of its components, given the quantity of the aggregate. 
The weight assigned the price of each component is the ratio of its volume to the volume of the aggregate. In Leontief case (fixed-proportion aggregate), the weights do not change in response to relative price changes, while they do in other cases, depending on the elasticity of substitutability and transformation. The unit cost of an industry's output is therefore a weighted sum of the value-added prices and aggregate intermediate prices, as described by

$$
P P_{j}=\frac{P V A_{j} V A_{j}+P C I_{j} C I_{j}}{X S T_{j}}
$$

The value accounting identity is therefore

$$
P P_{j} X S T_{j}=P V A_{j} V A_{j}+P C I_{j} C I_{j} .
$$

The prices of other aggregates follow the same principle. For instance, the aggregate intermediate price is a combination of the commodity prices of the industry's intermediate, and value-added price is a combination of the prices of composite labor and capital used in the production.

Price of international trade: Since exporting industries can sell their outputs in both international and domestic market, the price of their aggregate production is a weighted sum of the price obtained in each market. The weights change in relation to variation in relative price, following CET function. The basic price $\left(P_{j, i}\right)$ received by industry $j$ is a weighted sum of its basic price on the domestic market and on the export market, while the FOB price, including margins $\left(\operatorname{tmrg}_{i j, i}^{X}\right)$ and export taxes $\left(t^{t i x}{ }_{i}\right)$, paid by purchasers on the export market is different from the price obtained by producers. The basic price and the FOB price are given by the following equations:

$$
\begin{aligned}
& P_{j, i}=\frac{P E_{i} E X_{j, i}+P L_{i} D S_{j, i}}{X S_{j, i}} \\
& P E_{i}^{F O B}=\left(P E_{i}+\sum_{i j} P C_{i j} t m r g_{i j, i}^{X}\right)\left(1+t t i x_{i}\right)
\end{aligned}
$$

On the domestic market, the price of the composite commodities is a weighted sum of the price paid for domestically produced goods and imported goods. The former is the sum of the price obtained by producers, indirect taxes, and margins, whereas the latter is the world price in terms of the local currency, combined with import taxes and duties, indirect taxes, and margins.

\subsubsection{Gross domestic product (GDP)}

There are four types of GDP in the model.

1. $\mathrm{GDP}^{\mathrm{BP}}=\sum_{j} \mathrm{PVA}_{j} \mathrm{VA}_{j}+\mathrm{TIPT}:$

GDP at basic price is equal to payments made to value added and taxes on production other than taxes on labor and capital already included in factor costs. 


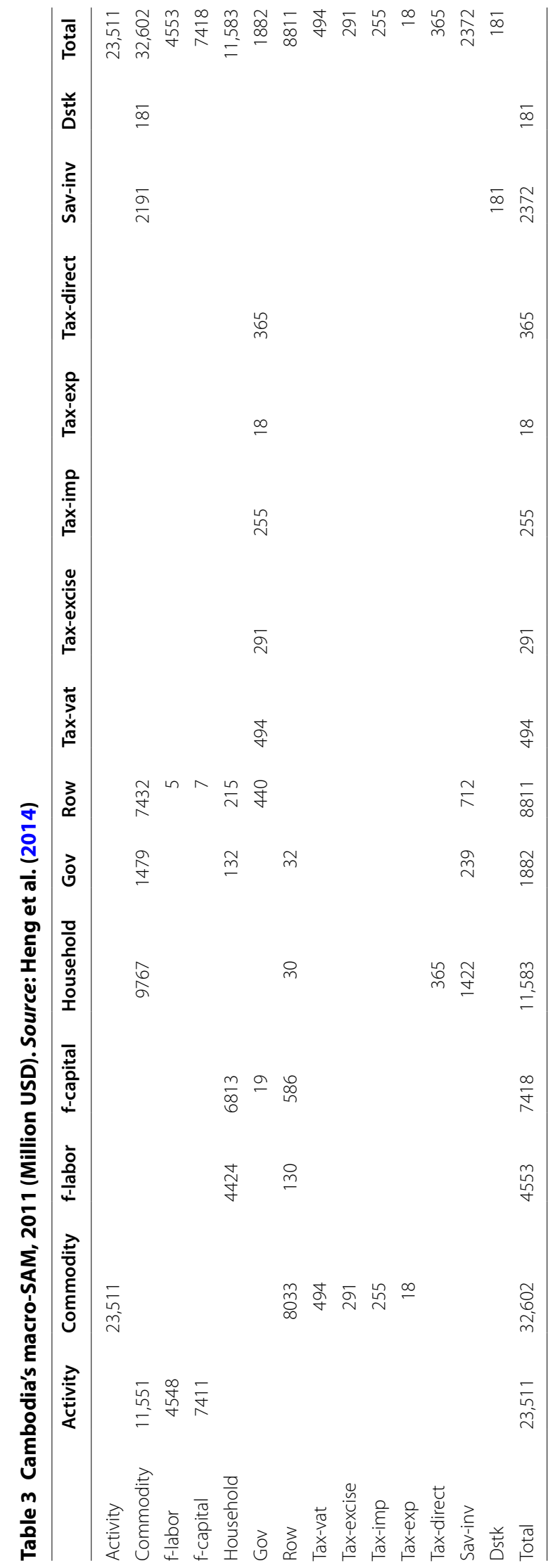


2. $\mathrm{GDP}^{\mathrm{MP}}=\mathrm{GDP}^{\mathrm{BP}}+\mathrm{TPRCTS}$ :

GDP at market price is equal to GDP at basic price plus amount of taxes in products and imports.

3.

$$
\mathrm{GDP}^{\mathrm{FD}}=\sum_{i} \mathrm{PC}_{i}\left[\sum_{h} C_{i, h}+\mathrm{CG}_{i}+\mathrm{INV}_{i}+\mathrm{VSTK}_{i}\right]+\sum_{i} \mathrm{PE}_{i}^{\mathrm{FOB}} \mathrm{EXD}_{i}-e \sum_{i} \mathrm{PWM}_{i} \mathrm{IM}_{i}:
$$

GDP at market price from the final demand perspective is the total of net final demand expenditure, which includes household consumption, government expenditure, investment demand, and the value of net exports.

4.

$\mathrm{GDP}^{\mathrm{IB}}=\sum_{l, j} W_{l} \mathrm{LD}_{l, j}+\sum_{k, j} R_{k, j} \mathrm{KD}_{k, j}+\mathrm{TPRODN}+\mathrm{TPRCTS}:$

GDP at market price from the income perspective is the total income of labor and capital, plus taxes on production and taxes on products and imports.

\subsection{Basic characteristics of the SAM}

Social accounting matrix (SAM) presents the system of national accounts of an economy at a particular period and summarizes its structure of both internal and external links and the roles of different actors (Burfisher 2011; Vos 2007). Each entry traces out the circular flow of income and payments of all economic activities including production, factor inputs, institutions, and commodity demand. Since the income-expenditure accounts of each agent of corresponding row and column must balance-the total income from all sources must equal to the total expenditure, SAM must balance exactly and, thus, must be a square matrix.

With a few modifications, the study uses the Cambodia's aggregated SAM, adopted from Heng et al. (2014) under publication in PEP Research Network. The SAM was built following the structure of ADB's Supply-Use Table and basing on various sources of survey data including national account, government budget, customs tariff, balance of payment, and household surveys. The structure of Cambodia's macro-SAM is shown in Table 3. The number of activities, factor inputs, agents, and household types of the final SAM applied in the current study is listed below:

- Production: 16 activities, 22 commodities, with the description in Table 4

- Factors: 1 type of capital, 3 types of labor: low-skilled, medium-skilled, high-skilled

- Agents: 3 types of agents: government, household, rest of the world

- Households: 6 categories (according to living areas and living standard levels): other urban poor (UP), other urban non-poor (UNP), rural poor (RP), rural non-poor (RNP), Phnom Penh poor (PPP), Phnom Penh non-poor (PPNP).

\subsection{Economic structural feature in the base scenario}

Table 5 shows the basic structural feature of Cambodian economy at the base scenario of the SAM 2011. Agriculture and textile account for the highest share in production, at

\footnotetext{
${ }^{5}$ Phnom Penh is Cambodia's capital city, which has quite different characteristics from other urban areas.
} 
Table 4 Industries and commodities in the Cambodia's SAM, 2011. Source: Heng et al. (2014), aggregated by Author

\begin{tabular}{|c|c|c|c|}
\hline No. & Activities & No. & Commodities \\
\hline 1. AGR & Agriculture & 1. AGR & Agriculture \\
\hline 2. FBT & $\begin{array}{l}\text { Manufacture of food products, bever- } \\
\text { ages, and tobacco }\end{array}$ & 2. FBT & Food, beverages, and tobacco \\
\hline 3. TEXTILE & $\begin{array}{l}\text { Manufacture of textiles, wearing } \\
\text { apparel, and footwear }\end{array}$ & 3. TEXTILE & $\begin{array}{l}\text { Clothing and wearing apparel; and } \\
\text { leather and leather products }\end{array}$ \\
\hline 4. WP & $\begin{array}{l}\text { Manufacture of wood, wood products, } \\
\text { paper, and paper products }\end{array}$ & 4. WP & $\begin{array}{l}\text { Products of wood, paper, and paper } \\
\text { products }\end{array}$ \\
\hline 5. RP & $\begin{array}{l}\text { Manufacture of rubber and plastic } \\
\text { products }\end{array}$ & 5. RP & Rubber and plastics products \\
\hline 6. METAL & Manufacture of basic metals & 6. METAL & Basic metals \\
\hline \multirow[t]{3}{*}{ 7. FMETAL } & \multirow{3}{*}{$\begin{array}{l}\text { Manufacture of fabricated metal } \\
\text { products; and office and computing } \\
\text { machinery }\end{array}$} & 7. FMETAL & $\begin{array}{l}\text { Fabricated metal products, except } \\
\text { machinery and equipment }\end{array}$ \\
\hline & & 8. MACHINE & General and special purpose machinery \\
\hline & & 9. OFFICE & $\begin{array}{l}\text { Office, accounting, and computing } \\
\text { machinery }\end{array}$ \\
\hline 8. MOTORT & $\begin{array}{l}\text { Manufacture of motor vehicles and } \\
\text { other transport equipment }\end{array}$ & 10. TRANS & Transport equipment \\
\hline \multirow[t]{3}{*}{ 9. OTHMNU } & \multirow[t]{3}{*}{ Other manufacturing } & 11. OTHMNU & Other Manufacturing \\
\hline & & 12. CHEM & Basic chemicals and other chemicals \\
\hline & & 13. FURN & $\begin{array}{l}\text { Furniture and other transportable goods, } \\
\text { n.e.c. }\end{array}$ \\
\hline 10. MEGW & $\begin{array}{l}\text { Mining and quarrying, electricity, gas, } \\
\text { and water supply }\end{array}$ & 14. MEGW & $\begin{array}{l}\text { Coal and lignite, peat, crude petroleum, } \\
\text { and natural gas; other minerals; elec- } \\
\text { tricity, gas, and water }\end{array}$ \\
\hline 11. CON & Construction & 15. CON & Construction services \\
\hline 12. WTT & $\begin{array}{l}\text { Wholesale, retail trade, and transport } \\
\text { service }\end{array}$ & 16. WTT & $\begin{array}{l}\text { Wholesale, retail trade, and transport } \\
\text { service }\end{array}$ \\
\hline 13. HR & Hotels and restaurants & 17. HR & $\begin{array}{l}\text { Lodging, food, and beverage serving } \\
\text { services }\end{array}$ \\
\hline 14. FBUS & $\begin{array}{l}\text { Financial intermediation-insurance, real } \\
\text { estate-business services, post and } \\
\text { telecommunication }\end{array}$ & 18. FBUS & $\begin{array}{l}\text { Financial intermediation and insurance; } \\
\text { real estate and business services; post } \\
\text { and telecommunication }\end{array}$ \\
\hline \multirow[t]{3}{*}{ 15. AEH } & \multirow[t]{3}{*}{$\begin{array}{l}\text { Public administration and defense, } \\
\text { education, health and social work }\end{array}$} & 19. ADM & $\begin{array}{l}\text { Public administration and compulsory } \\
\text { social security services }\end{array}$ \\
\hline & & 20. EDU & Education services \\
\hline & & 21. HEALTH & Health and social services \\
\hline 16. OTHSER & Other community service activities & 22. OTHSER & Other services, n.e.c. \\
\hline
\end{tabular}

22 and $21 \%$, respectively, followed by construction (CON) and food-beverage-tobacco (FBT) in the industrial sectors, while wholesales-retail trade and transportation (WTT) has the highest output share (15\%) among service sectors, followed by finance-business (FBUS) and hotel-restaurant (HR). Agriculture, WTT, CON, FBUS, and FBT are also the top sectors sharing the highest domestic demand for commodities produced locally, which also means they are less dependent on import requirement to satisfy domestic demand. The figures, however, infer that any changes that occur in these sectors would induce high impacts on total domestic production. The table also shows export and import share in total values. Textile alone accounts for $67 \%$ of total exports, given the advantage of duty-free access to the EU and the US market; the next main export sectors are in services, particularly hotel-restaurant and WTT. On the other hand, Cambodia 





imports a significant amount of textile and chemical for both intermediate and consumer goods, whereas high imports of other manufacturing (OTHMNU) are mainly consumer goods such as electrical equipment and household appliance.

For the export and import intensity, defined as export share in total production and import share in total composite demand, textile, office, and machinery have high share in both export and import intensity, which reveals that these commodities are highly export-oriented, while domestic market is mostly satisfied by imported goods. For these sectors, domestically produced goods for domestic consumption are far behind the level of self-sufficiency. In contrast, hotel-restaurant has the export intensity of $71 \%$, showing the importance of this service, especially in the tourism sector, yet with less dependent on import for domestic consumption. It should be noted that food-beverage-tobacco, rubber, and agriculture account for a small share in both exports in total values as well as exports in production.

Finally, the share of employment in total labor force varies widely between sectors, ranging from the highest in agriculture (48\%), WTT (18\%), and textile (6\%), to the lowest in MOTORT (0.1\%) and METAL (0.4\%). Each of the remaining industrial sectors, except CON and FBT, employs less than $1 \%$ of total labor, while the rest of services shares an average of $4 \%$, reflecting that employment is highly concentrated in a few manufacturing sectors. Having a look at the division of labor by skill would show a clearer industrial employment pattern. Most of the industrial sectors are low-skilled intensive, which can be common in low-income countries, while most service sectors, except HR and WTT, employ a larger share of high-skilled labor. However, those services are still at the low level in contribution to both production and export.

\subsection{Household income and expenditure estimations}

To make it fit with the purpose, the study modifies the household account into six new categories according to urbanization and living standard level, by generating the data of both income and expenditure from Cambodia Socio-Economic Survey dataset (National Institute of Statistics 2009). This new household account contributes to the originality of the SAM applied in the study. The households receive income from different sources: labor income, capital income, transfers from government and from rest of the world. First, labor income is categorized by sectors and skill levels, assumed to be determined by education attainment: low-skilled (up to grade 5), medium-skilled (grade 6 to 10), and high-skilled (grade 11 and above).

Second, labor income should take into account both formal employees and selfemployed workers in both primary and secondary occupation because it is common that one person may have more than one jobs at a time (one full-time and one part-time job) due to the low wage level in Cambodia; however, the household survey records only the wage of employees and only the wage of their primary jobs. To avoid underestimation of the labor income, average earning per hour of employees by sectors and by skill level is calculated, and it is assumed that the self-employed, as well as all workers taking secondary jobs, receive the same average wage. Total income of all the groups of workers can then be calculated by multiplying the average wage by the working hours per week/ year. Third, these income data are differentiated by living areas (Phnom Penh, other urban, and rural) and by living standard level (poor and non-poor), identified based on 
Table 6 Estimation of household income in the SAM. Source: Author's calculation based on CSES (2009) and SAM 2011

\begin{tabular}{|c|c|c|c|c|c|c|c|}
\hline & $\begin{array}{l}\text { Low- } \\
\text { Skilled } \\
\text { Labor } \\
\text { (LSK) }\end{array}$ & $\begin{array}{l}\text { Medium- } \\
\text { Skilled } \\
\text { Labor } \\
\text { (MSK) }\end{array}$ & $\begin{array}{l}\text { High- } \\
\text { Skilled } \\
\text { Labor } \\
\text { (HSK) }\end{array}$ & Capital & Government & $\begin{array}{l}\text { Rest } \\
\text { of the } \\
\text { World } \\
\text { (RoW) }\end{array}$ & Total \\
\hline \multicolumn{8}{|l|}{ From SAM } \\
\hline Household income & 2982.0 & 2067.2 & 1064.6 & 5110.8 & 132.1 & 226.7 & $11,583.5$ \\
\hline \multicolumn{8}{|l|}{ From CSES } \\
\hline \multicolumn{8}{|c|}{ Shares of income by sources } \\
\hline othurban poor & $1.6 \%$ & $1.7 \%$ & $1.8 \%$ & $0.0 \%$ & $0.5 \%$ & $1.3 \%$ & $1.7 \%$ \\
\hline othurban non_poor & $5.8 \%$ & $12.5 \%$ & $17.3 \%$ & $29.1 \%$ & $21.4 \%$ & $21.5 \%$ & $10.1 \%$ \\
\hline othrural poor & $21.7 \%$ & $10.9 \%$ & $1.8 \%$ & $0.4 \%$ & $8.6 \%$ & $6.5 \%$ & $14.8 \%$ \\
\hline othrural non_poor & $66.1 \%$ & $60.7 \%$ & $29.6 \%$ & $32.0 \%$ & $49.1 \%$ & $43.0 \%$ & $59.0 \%$ \\
\hline pp poor & $0.7 \%$ & $1.6 \%$ & $2.2 \%$ & $2.2 \%$ & $0.5 \%$ & $0.6 \%$ & $1.2 \%$ \\
\hline pp non_poor & $4.3 \%$ & $12.6 \%$ & $47.3 \%$ & $36.3 \%$ & $20.0 \%$ & $27.1 \%$ & $13.3 \%$ \\
\hline Total & $100.0 \%$ & $100.0 \%$ & $100.0 \%$ & $100.0 \%$ & $100.0 \%$ & $100.0 \%$ & $100.0 \%$ \\
\hline \multicolumn{8}{|l|}{ Incorporate into SAM } \\
\hline \multicolumn{8}{|l|}{ Income by sources } \\
\hline othurban poor & 47.0 & 36.2 & 19.1 & - & 0.6 & 2.9 & 105.7 \\
\hline othurban non_poor & 172.5 & 259.2 & 183.8 & 1488.8 & 28.2 & 48.8 & 2181.3 \\
\hline othrural poor & 645.8 & 225.9 & 19.4 & 18.9 & 11.3 & 14.7 & 936.0 \\
\hline othrural non_poor & 1969.7 & 1253.8 & 315.4 & 1633.3 & 64.8 & 97.4 & 5334.4 \\
\hline pp poor & 19.6 & 32.3 & 23.9 & 112.4 & 0.7 & 1.4 & 190.3 \\
\hline pp non_poor & 127.5 & 259.8 & 503.1 & 1857.4 & 26.5 & 61.4 & 2835.8 \\
\hline Total & 2982.0 & 2067.2 & 1064.6 & 5110.8 & 132.1 & 226.7 & $11,583.5$ \\
\hline
\end{tabular}

othurban poor other urban poor, othurban non_poor other urban non-poor, pp poor Phnom Penh poor, pp non_poor Phnom Penh non-poor, LSK low-skilled, MSK medium-skilled, HSK high-skilled

daily expenditure following poverty line definition by the Ministry of Planning (National Institute of Statistics 2013). The same differentiation is also applied to other sources of household income-capital and transfers. Finally, shares of each category of the income sources are incorporated into the SAM by utilizing the original table serving as control totals, as shown in Table 6.

The estimation is also done for the household expenditure on different sources: commodities, direct taxes, transfers to rest of the world, and saving/investment. The former three are generated from recorded household spending on food and non-food items, in which the commodities are mapped using the corresponding table of ISIC rev.4 (applied in the CSES) with the CPC rev.1.1 (applied in the SAM), while saving account is a residual between income and expenditure.

\section{Export and growth: simulation and analysis}

\subsection{Analytical framework}

The analysis follows the framework summarized in Fig. 3. The target toward export orientation is captured through the connection between the foreign market and domestic market, both links to product and factor market through industrial activities. Industries consume intermediate and factor inputs and pay factor costs to the labor and capital in the factor market, whereas households receive income from factor payment and spend 


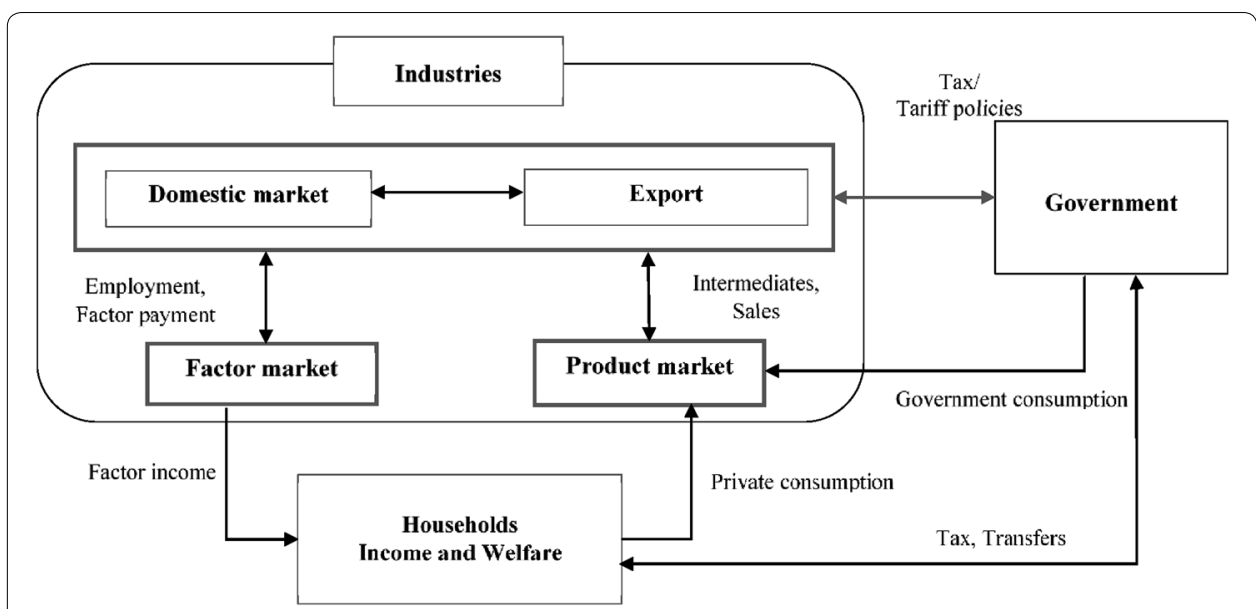

Fig. 3 Conceptual framework of the study. Source: Author's creation, based on Ganuza et al. (2005)

for consumption. Another important account is the government which interacts with others through various transactions. For instance, the government receives taxes from and provides transfer payments to households, and spends on consumption. In addition, the government may operate some complementary policies in the factor market, such as the change in wage policy and the initiative of a special training scheme to increase productivity. More importantly, the government is expected to play a vital role to promote export orientation of selected industries through various preferential policy measures including tax/subsidy and tariff implementation. The transactions will finally determine impacts on supply and demand of every agent and household welfare. Welfare is represented by minimum expenditure to maximize utility. The study measures household welfare through the equivalent variation (EV) in percentage of initial income which estimates the differences between household minimum consumption budget and total consumption budget available after each simulation. A higher EV represents a larger remaining budget and, thus, a higher welfare.

Typical CGE models, as well as the standard PEP model, usually determine a fixed supply of factors (capital and labor), while wages/rental rates adjust to clear the market with full employment to achieve demand-supply equilibrium, specified by Eq. (15). However, to be more realistic and for the short-run framework, the model can specify unemployment cases which are common in developing countries (Burfisher 2011; Vos 2007). For instance, Sánchez and Sauma (2006) assumed that there could be unemployment in various labor market segments in the Costa Rica general equilibrium framework while fixing real wage and allowing labor supply to clear the labor market. Therefore, to capture the labor market characteristic of Cambodia's economy, the study assumes an unemployment labor market by introducing an unemployment variable, as appeared in Eq. (16) while keeping labor supply exogenous and wage endogenous, instead of assuming unlimited labor supply.

$$
\begin{aligned}
\mathrm{LS}_{l} & =\sum \mathrm{LD}_{l, j} \\
\mathrm{LS}_{l} & =\sum \mathrm{LD}_{l, j}\left(1+U_{l}^{\phi_{l}}\right)
\end{aligned}
$$


where $\mathrm{LS}_{l}$ is labor supply of type $l$ labor, $\mathrm{LD}_{l, j}$ is demand for type $l$ labor by industry $j, U_{l}$ is unemployment rate of type $l$ labor, and $\phi_{l}$ is the elasticity of unemployment and wage rate of type $l$ labor.

Following the theoretical framework of wage curve by Blanchflower and Oswald (1994), a relationship between the wage rate and local unemployment rate can be described by:

$$
W_{l}=a_{l} U_{l}^{f_{l}}
$$

where $W_{l}$ is wage rate of type $l$ labor, and $a_{l}$ is a coefficient between unemployment rate and wage rate of type $l$ labor.

The baseline wage rate is set to 1 for all types of labor, whereas initial unemployment figures are set to $20 \%$ for low-skilled, $15 \%$ for medium-skilled, and $10 \%$ for high-skilled labor as it is assumed that high-skilled labor finds it easier to enter the labor market and more likely to be employed. The modification in the model contributes to the originality of the study.

\subsection{Macroclosure}

For the model to assess the economic outcomes, the study determines a set of macroclosure as follows.

- Capital is immobile and in full employment due to the short-term assumption that capital is sector-specific and capital demand is equal to capital supply.

- Labor is assumed mobile across sector, specifying that labor can move from one sector to another to get employed. Labor supply is exogenous. The study specifies two types of closure for labor market: Closure 1 assumes equilibrium labor market, in which there is no unemployment (the standard model); closure 2 assumes that there is unemployment in the labor market (modified model).

- Saving rates are fixed, and saving adjusts to ensure macroeconomic equilibrium, following investment saving-driven framework.

- World export price and world import price are exogenous, following small-country hypothesis.

- Current account balance is exogenous.

- Nominal exchange rate acts as numeraire, which specifies that all the prices change relatively to the changes of numeraire.

\subsection{Simulation designs}

To capture the full impacts of export sectors, the study performs a series of simulations divided into three main exercises: external shocks, internal shocks, and the combination of the two shocks, listed in detailed in Table 7. The study focuses on export orientation of three sectors: food-beverage-tobacco and rubber (both as agro-manufacturing industry) and agriculture. The first scenario focuses on the changes in external demand which assumes a US $\$ 10$ million increase in export demand for food and rubber products (simulation 1A) and for agricultural products (simulation 1B). This assumption owes to the progress of significant changes underway the demand for these products, specifically 
Table 7 Simulation designs

\begin{tabular}{|c|c|}
\hline Scenarios & Simulation designs \\
\hline \multicolumn{2}{|l|}{ External shocks } \\
\hline \multirow[t]{2}{*}{ 1. World demand } & 1A. US\$10 mil. increase in export demand for agro-products \\
\hline & 1B. US\$10 mil. increase in export demand for agriculture \\
\hline \multicolumn{2}{|l|}{ Internal shocks } \\
\hline \multirow[t]{2}{*}{ 2. Productivity } & $\begin{array}{l}\text { 2A. } 10 \% \text { increase in low- and medium-skilled labor productivity of the } \\
\text { selected export sectors }\end{array}$ \\
\hline & 2B. $10 \%$ increase in labor productivity of all skills of all sectors \\
\hline \multicolumn{2}{|l|}{ External and internal shocks } \\
\hline 3. World demand and productivity & 3. $1 A+1 B+2 B$ \\
\hline
\end{tabular}

for the ready-made processed food in Asia with growing population and more households graduating to middle-income groups. Also, more developing countries are moving up to medium and high technological production while reducing their supply dependence on agriculture and agro-processing.

The second set of scenario assumes a $10 \%$ increase in labor productivity across the board in all the sectors (simulation 2A) and the same change but only of low-skilled and medium-skilled labor in the selected sectors (simulation $2 \mathrm{~B}$ ). The increase in labor productivity is needed to increase supply efficiency in response to demand changes. These simulations also compare skill intensity in trade sectors, referring to which types of labor (low-skilled, medium-skilled, or high-skilled) are more demanded proportionately in the production of different goods. The demand for labor may rise or fall depending on the types of labor that are more important in the targeted sectors. Are agriculture, food, and rubber production more skilled intensive? This question can be addressed by examining what happens to labor demand when there is production disturbance.

The last scenario is the combination of the simulations $1 \mathrm{~A}, 1 \mathrm{~B}$, and $2 \mathrm{~B}$ as the result of both the increase in demand for agro-industry and agriculture sector and the increase in productivity of low- and medium-skilled labor in both sectors. Once the targeted sectors have been identified and promoted for export orientation, domestic policy measures could be adopted for enhancement of productivity rather than depending solely on the external pattern.

\subsection{Results and discussion}

The results of the three exercises are expected to point out the roles of the promising export sectors and the productivity measure that can be feasible to promote export orientation. ${ }^{6}$ The study discusses the simulation results based on two different closures: Closure 1 is the labor market equilibrium closure (the standard model), and closure 2 is the economy with unemployment (the modified model). Favorable impacts on the domestic economy and employment are desirable; however, this should not be achieved by sacrificing household welfare. The interpretation of the results, therefore, focuses on the following indicators: (1) macroeffects which include real GDP, investment, and government consumption; (2) sectoral and employment effects, particularly exports,

\footnotetext{
${ }^{6}$ Tables of results are given in "Appendix 3." Sensitivity analysis (given in "Appendix 4") confirms that the results are robust in response to changing Armington and export (CET) elasticity.
} 
imports, output, value added, and labor demand (by sector and by skill group); and (3) household effects which may cover consumption, income, and welfare.

\subsubsection{Impacts of external demand shocks}

An increase in export demand in the first scenario would result in an increase in GDP, total investment, and production. Under both macroclosures, the increase in agroexports (sim 1A) induces higher, albeit small, impacts on most of the variables comparing to the rise in agriculture exports (sim 1B) although they follow similar trends. However, the demand disturbances produce smaller changes in magnitude under the labor market equilibrium closure (closure 1). For instance, as Fig. 4 shows, GDP increases by only $0.26 \%$ in simulation $1 \mathrm{~A}$ and $0.02 \%$ in simulation $1 \mathrm{~B}$ under closure 1 , compared to 0.77 and $0.58 \%$ in the two simulations, respectively, under closure 2 . These can be explained by the market adjustment under the economic equilibrium with full employment of labor and capital as there are almost no changes in value addition. In addition, since labor can move from one sector to another, the increase in production in agro-industry and agriculture due to the increase in export demand would require more labor from other sectors based on the change in wage rates to achieve the equilibrium in total labor demand and supply.

Under the unemployment labor market, nevertheless, the changes in macroeffects are more pronounced. Real GDP would rise by US $\$ 101$ million and total investment by US\$38 million in simulation 1A opposed to US\$76 million and US\$22 million, respectively, in simulation 1B, whereas aggregate output is one-half higher in the former compared to the latter simulation. Government income and savings see enormous progress, which can be explained by the increase in revenues from tax and tariff as a result of higher export supply and import demand, with bigger impacts on import, in both

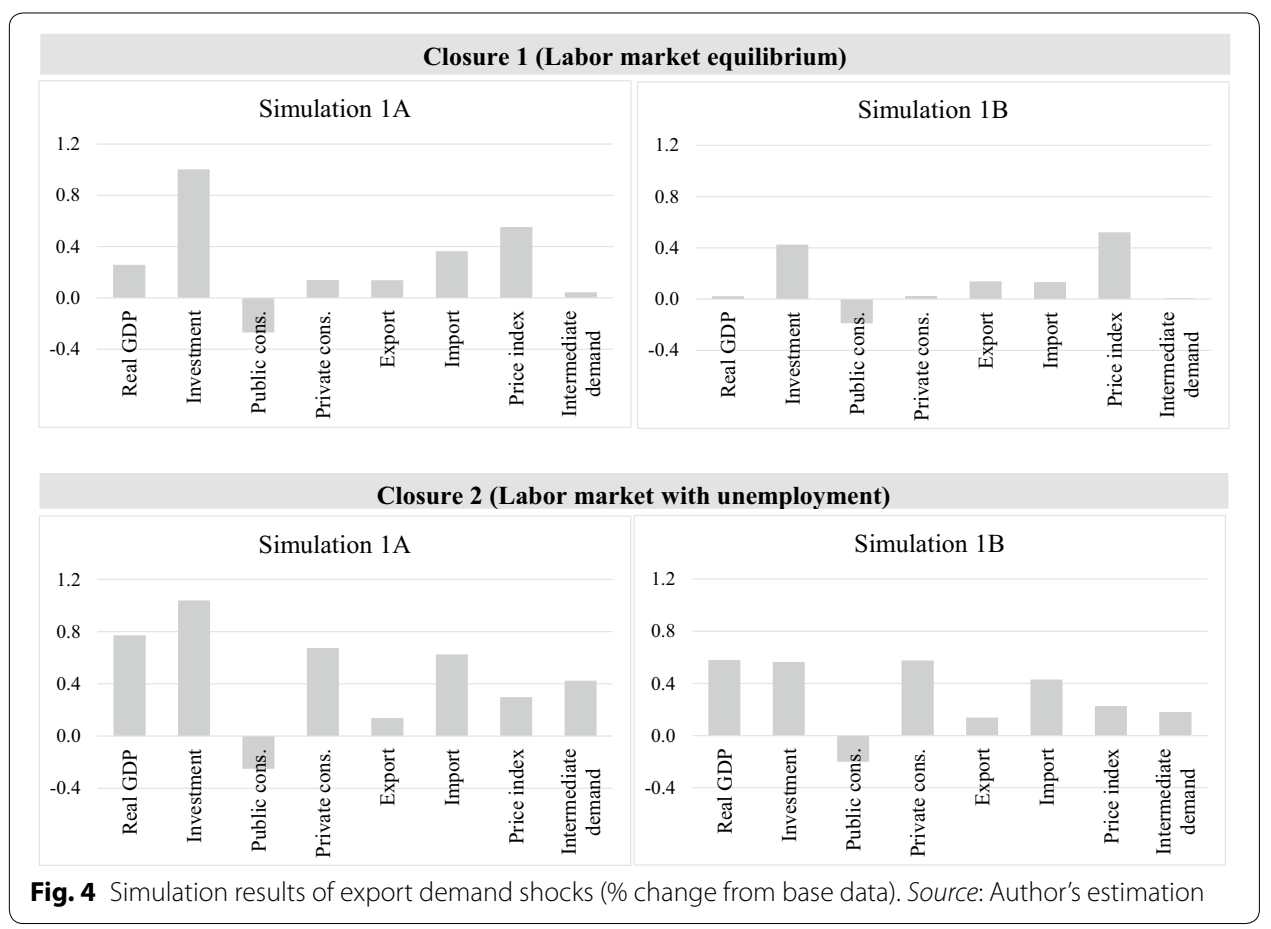


exercises. Public consumption, in contrast, faces negative impacts due to a rise in the price index, with higher effects in simulation $1 \mathrm{~A}$, as a result of reduction of domestic supply when producers find exports more profitable. However, the increase in price does not adversely affect private consumption; instead, it surges by 0.67 and $0.58 \%$ in the two exercises, respectively, whereas household welfare is better off, with the highest impact on rural households, due to the significant increase in income, especially the income from labor as a result of wage increase. Also, income propensity to agriculture and food consumption can be higher among rural groups than their urban/city peers.

Higher production to meet the increase in export requires more labor, leading to a decrease in unemployment by $0.64 \%$ in sim $1 \mathrm{~A}$ and $0.55 \%$ in sim $1 \mathrm{~B}$ under closure 2, with good impacts on all of the skill groups. Yet, low-skilled labor sees higher demand due to the low-skill intensity in agriculture and agro-related industry. It should be noted that the increase in labor demand does not happen only in the simulated industries but also in almost all of other industries due to the flow-on effects of production. This effect means that the three targeted industries highly connect to the rest of the economy. Another purpose of carrying out the simulations in set 1 is to assess the level of linkages of export sectors. The results suggest that the linkage between agriculture exports with the remaining industries is, in fact, lower than those of agro-manufacturing. In total, $0.18 \%$ of intermediate demand is needed to achieve US $\$ 10$ million agriculture export acceleration, while the same amount of export increase in agro-products would consume additional $0.42 \%$ of intermediate input.

\subsubsection{Impacts of internal shocks}

Productivity shock measures inter-industry and employment linkages and examines how export and import react-which sectors are likely to lead to output and employment generation-and whether the impacts will favor labor-intensive sectors (Ha and Swales 2012). In particular, supply disturbance scenario in the study attempts to measure linkage between the targeted export sectors and employment, and their skill-type intensity. The simulation results suggest that the increase in labor productivity, needed to increase production efficiency, is beneficial in general and strongly positive for GDP, income, and trade in particular, with the growth of exports higher than the growth of imports, depicted in Fig. 5. The results of both simulations 2A and 2B share a similar tendency, but with different impact sizes. Total exports surge more significantly in simulation $2 \mathrm{~A}$, under both closures. Nonetheless, it is interesting to note that at the sectoral level, agriculture and food export changes in both simulations are not diverging, with both accelerating within the range of 12.40 and $11.10 \%$ for agriculture and 10.91 and 9.08\% for processed food (closure 1). It can be inferred that these two sectors are more low- and medium-skilled intensive as the same effects would happen with the increase in productivity of either all the skill groups or only the specified low- and medium-skilled groups. This finding is consistent with the results from the earlier scenario which also showed that the targeted trade sectors are low-skilled and medium-skilled intensive. The rise in outputs would significantly lower consumer price and raise consumption of both public and household agents.

Under closure 1, total employment remains at the equilibrium although there is an increase in supply-side efficiency. Higher labor productivity is accompanied by the surge 


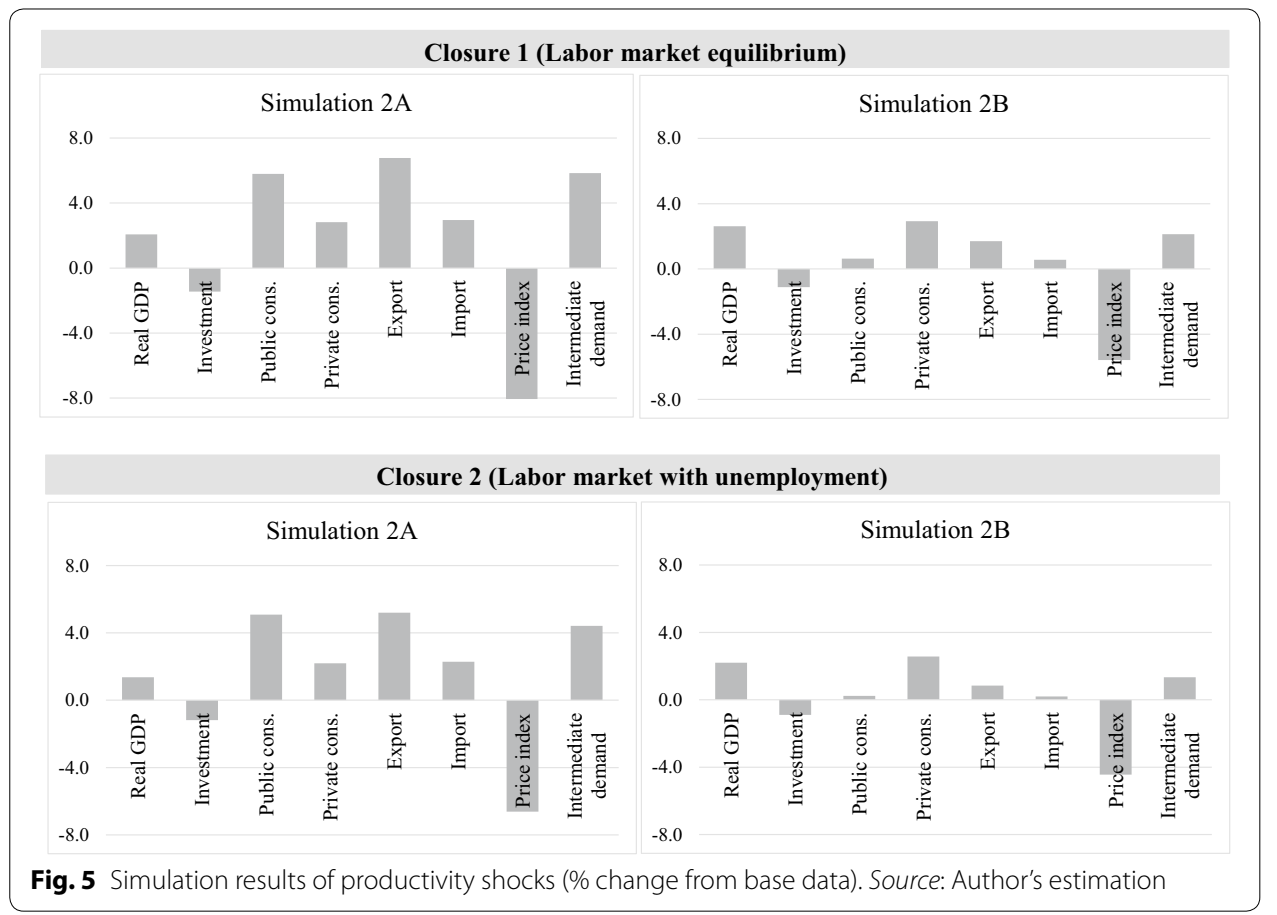

in the real wage, of which high-skilled labor sees the largest impact at 8.61\%, compared to 4.35 and 0.57 for the medium- and low-skilled in simulation $2 \mathrm{~A}$ and 5.32, 3.03, and $1.02 \%$ for the three skilled groups in simulation $2 \mathrm{~B}$. A few reasons can explain these different changes in the real wage. For one thing, wage of the low-skilled labor is relatively less rigid to adjust given a more flexible movement of this group between sectors as they are more likely to be employed within the informal job-contract system. Also, as opposed to their counterparts, those low-skilled labors are more easily substituted by capital, which is also the reason why the rates of return on capital in the real term increase in both simulations.

Under closure 2, the real wage changes produced by the two simulations are similar to that under the previous closure; nevertheless, the employment impacts are very different. The increase in labor productivity with disequilibrium labor market would result in a higher unemployment rates. When labor becomes more productive, wage rates surge, and thus the demand for labor by industry would decrease, given the same level of output supply. However, the results under this closure could be due to the limitation of the current study that undertakes the productivity impacts based on static modeling. It is suggested that the static models seem to underestimate the effects as they do not incorporate productivity and capital gains over time. In the case of developing countries, where unemployment persists, the increase in supply efficiency is crucial to level up the production chain and to upgrade the industrial structure, particularly to enhance the diversification from low-tech and labor-intensive to medium-tech industry, which requires labor with higher efficiency.

The purpose of running these two simulations is to compare how the growth in labor productivity across the board differs from that for only low-skilled and medium-skilled labor in the selected sectors. Although the impacts are more marginal in the former 


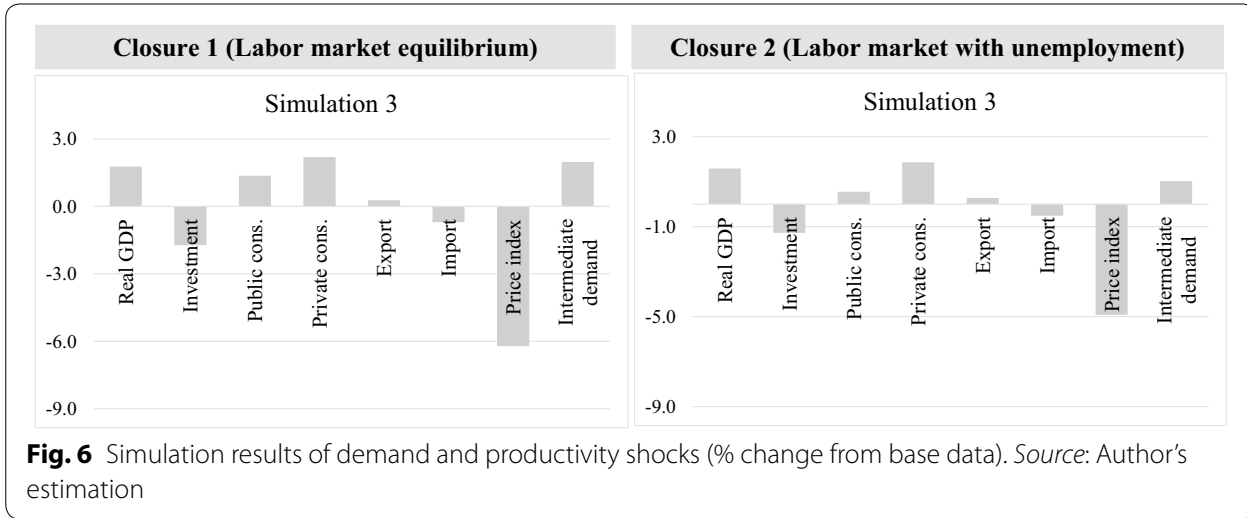

simulation, the latter happens to generate higher impacts on a few main indicators. For instance, real GDP improves by US $\$ 269$ million in the former, but US $\$ 340$ million in the latter simulation (closure 1). Similar effects can be seen at the household level, where household consumption soars by 2.82 and household income by $2.50 \%$ in simulation $2 \mathrm{~A}$, versus 2.93 and $2.78 \%$ for the same variables in simulation $2 \mathrm{~B}$. These suggest that household would benefit more if the productivity attainment focuses more on the specified low- and medium-skilled groups at the specified sectors rather than otherwise on unspecific target. A more positive result could happen if the improvement in labor efficiency is combined with an increase in export demand. Nevertheless, household welfare variations in both simulations parallel, with more influence on other urban poor group and rural group, implies that scaling up productivity can be a valuable tool to raise the welfare of the rural and urban poor households. It is worth noting that the estimated labor productivity in Cambodia grew by $5.1 \%$ as an annual average during 2005-2013 (Asian Productivity Organization 2015). This figure needs to be significantly increased in order for the economy to capture the benefits that the productivity generates.

\subsubsection{Impacts of external and internal shocks}

The last simulation, which combines the demand and supply disturbance as a measure for export sector promotion, produces the results that favor the economy at a large scale. Figure 6 shows the results on the macroeffects. In response to the demand and efficiency improvement, production output increases by 2.20 and 1.12 under closures 1 and 2, respectively, leading to the fall in consumer price, whereas private and public consumption soar substantially in response to the decline in price index. The fall in price results in the decrease in imported products, replaced by a higher demand for domestically produced goods. As a result, GDP increases by almost $2 \%$ under both closures. Yet, there is an inverse effect on government savings to finance the decline in investment.

The changes of the factor inputs share a similar pattern to those in the scenario two that the increase in export demand and labor efficiency would substantially raise the remuneration of both labor and capital as more factor inputs are needed to keep up with higher production output, particularly in the sectors with higher impacts. Under closure 2 in which there is unemployment in the labor market, however, with an increase in labor efficiency, there is a reduction in the labor intensity of production. The impacts on 
the economy are slightly less substantial as they are offset by the decline in employment when labors become more efficient. Nonetheless, real wage increases more marginally.

Unsurprisingly, household welfare, as a percentage of initial income, surges noticeably at the level of 1.81 on average under closure 1 and 1.47 under closure 2, in which rural poor and urban poor household see the highest impacts due to an increase in private consumption within these groups of household.

\section{Conclusion}

The study shows the roles of the selected sectors-food-beverage-tobacco, rubber, and agriculture-in stimulating export orientation through external trade movement as well as internal disturbance. The impacts of the potential sectors in response to export demand expansion bring positive economic growth and employment at the macrolevel, broaden production diversification at the sectoral level, and improve welfare at the household level, particularly the rural poor. The simulation results also point out that, at the current economic pattern, the contribution and inter-connection of agro-manufacturing sectors are larger than that of agriculture. Therefore, priority should be given to creating production chains from agriculture to processed food and processed rubber. This target is also in line with the government's aims to undertake some degree of processing inside the country before exporting and to increase the total share of processed agricultural exports set in the Industrial Development Plan 2015-2025 (Ministry of Commerce 2014; Royal Government of Cambodia 2015). Milled rice export policy initiated by the government in 2010, for example, has been an important road map for a significant improvement in this sector although the targeted export volume was not achieved by the timeline. Besides milled rice, however, there is a lack of critical and strategic attention to promoting other industrial food processing regardless of viable increasing export opportunity in the recent years. A more critical policy toward this sector is required not only to create the value chains, but also to reduce too much concentration on garment export to minimize the high vulnerability resulting from possible changes in world price and competitiveness within the garment sector. These findings are also consistent with previous studies which suggested that agriculture and food industry contribute better to domestic income, while garment cannot secure long-term distribution and competition (Chan and Oum 2011; Kobayashi et al. 2009; Kobayashi et al. 2008; Chhuor 2016).

The analysis also reveals that the exporting sectors are low-skilled and medium-skilled intensive, reflecting the higher increase in demand for those two groups to keep up with the growth in production and export supplies. The supply-side disturbance generates a high increase in economic output through the stimulus in both the selected sectors and other sectors. On the one hand, the increased efficiency produces higher production activity in the targeted sectors. On the other hand, there will be positive impacts on the competitiveness of other sectors when using the reduced price of goods from the targeted sectors as intermediate.

Therefore, the impacts on the economy and labor income could be larger if the efforts toward export orientation are coupled with the initiative to increase labor productivity of the low- and medium-skilled groups. This can be done through higher investment in education and vocational training according to labors' educational attainment 
in different sectors, provision of necessary skills within agro-manufacturing industries and agriculture, and encouragement of hands-on experience exchange between local and foreign specialists. For the economy to expand the benefits that the export demand may generate, the market needs an enable environment for the improvement of factor efficiency within the targeted sectors to bring favorable impacts on the economic growth and employment.

Acknowledgements

The author would like to thank Professor FUJIKAWA Kiyoshi, Dr. Christian S. Otchia, Mr. EAR Sothy, and two anonymous referees for their helpful guidance and comments.

Competing interests

The author has no competing interests.

Availability of data and materials

The data are available upon request to author.

Consent for publication

Not applicable.

Ethics approval and consent to participate

Not applicable.

\section{Appendix 1}

See Table 8.

Table 8 Target share of export sectors (percentage in total exports). Source: Industrial Development Plan 2015-2025 (RGC 2015)

\begin{tabular}{|c|c|c|c|c|c|c|}
\hline Sector & $1998(\%)$ & $2008(\%)$ & $2013(\%)$ & $2015(\%)$ & $2020(\%)$ & $2025(\%)$ \\
\hline Processed agricultural products & 10.0 & 10.0 & 7.9 & 8.0 & 10.0 & 12.0 \\
\hline $\begin{array}{l}\text { Garment and footwear manufacturing } \\
\text { products }\end{array}$ & 80.0 & 70.0 & 77.0 & 60.0 & 55.0 & 50.0 \\
\hline $\begin{array}{l}\text { Non-garment and footwear manufacturing } \\
\text { products }\end{array}$ & 0.1 & 0.5 & 1.0 & 5.0 & 10.0 & 15.0 \\
\hline
\end{tabular}




\section{Appendix 2}

Table 9.

Table 9 Positioning levels of the 19 products and services. Source: MoC (2007)

\begin{tabular}{|c|c|c|c|c|c|c|c|}
\hline & \multicolumn{5}{|c|}{ Export potential } & \multicolumn{2}{|c|}{ Human development } \\
\hline & $\begin{array}{l}\text { Estimated } \\
\text { export } \\
\text { in } 2005 \text { (\$ } \\
1000)\end{array}$ & $\begin{array}{l}\text { 1. Export } \\
\text { perfor- } \\
\text { mance }\end{array}$ & $\begin{array}{l}\text { 2. World } \\
\text { markets }\end{array}$ & $\begin{array}{l}\text { 3. Domes- } \\
\text { tic supply } \\
\text { condition }\end{array}$ & $\begin{array}{l}\text { Export } \\
\text { potential } \\
\text { assessment } \\
\text { (average } 3 \\
\text { indices) }\end{array}$ & $\begin{array}{l}\text { Estimated } \\
\text { employ- } \\
\text { ment }\end{array}$ & $\begin{array}{l}\text { 4. Human } \\
\text { develop- } \\
\text { ment } \\
\text { assessment }\end{array}$ \\
\hline \multicolumn{8}{|l|}{ List 1} \\
\hline Garments & $2,610,766$ & $H(5.0)$ & $H(3.5)$ & $H(3.8)$ & $H(4.1)$ & $3,60,000$ & $\mathrm{H}$ \\
\hline Footwear & $1,56,513$ & $H(4.1)$ & $M(3.1)$ & $H(3.5)$ & $H(3.6)$ & 4500 & M \\
\hline Cassava & 13,000 & $L(1.2)$ & $H(5.0)$ & $H(3.5)$ & $H(3.5)$ & 4000 & L \\
\hline Rubber & 9095 & $L(1.2)$ & $H(3.9)$ & $H(4.5)$ & $H(3.2)$ & 40,000 & M \\
\hline Fishery & $1,00,000$ & $M(3.0)$ & $M(2.7)$ & $H(3.5)$ & $M(3.1)$ & $2,60,000$ & $\mathrm{M}-\mathrm{H}$ \\
\hline Rice & 200,000 & $H(5.0)$ & $L(1.2)$ & $M(3.0)$ & $M(3.1)$ & $2,940,000$ & $\mathrm{M}-\mathrm{H}$ \\
\hline Soybeans & 34,000 & $L(1.7)$ & $H(3.4)$ & $M(3.0)$ & $M(2.7)$ & 16,500 & $L-M$ \\
\hline $\begin{array}{c}\text { Cashew } \\
\text { nuts }\end{array}$ & 50,000 & $L(2.0)$ & $M(2.7)$ & $M(3.0)$ & $L(2.6)$ & 12,000 & M \\
\hline Silk & 4000 & $L(1.1)$ & $M(2.7)$ & $L(2.3)$ & $L(2.0)$ & 20,500 & $\mathrm{M}-\mathrm{H}$ \\
\hline Livestock & 19,000 & $L(1.4)$ & $M(3.1)$ & $L(1.3)$ & $L(1.9)$ & 400,000 & M \\
\hline Corn & 25,000 & $L(1.5)$ & $L(1.2)$ & $L(2.5)$ & $L(1.7)$ & 12,500 & $L-M$ \\
\hline Beer & 975 & $L(1.0)$ & $M(2.8)$ & $L(1.0)$ & $L(1.6)$ & 3000 & L \\
\hline \multicolumn{8}{|l|}{ List 2} \\
\hline $\begin{array}{l}\text { Fruits and } \\
\text { vegeta- } \\
\text { bles }\end{array}$ & 269 & $L(1.0)$ & $H(3.2)$ & M & M & - & $\mathrm{M}-\mathrm{H}$ \\
\hline $\begin{array}{l}\text { Wood prod- } \\
\text { ucts }\end{array}$ & 5547 & $L(1.1)$ & $M(2.9)$ & M & M & - & M \\
\hline $\begin{array}{l}\text { Light manu- } \\
\text { facturing }\end{array}$ & 3336 & $L(1.1)$ & $H(3.3)$ & M & M & - & M \\
\hline Tourism & - & $\mathrm{H}$ & $\mathrm{H}$ & M & $\mathrm{H}$ & - & $\mathrm{H}$ \\
\hline $\begin{array}{l}\text { Labor } \\
\text { services }\end{array}$ & - & M & $\mathrm{H}$ & M & M & - & M \\
\hline $\begin{array}{l}\text { Web-based } \\
\text { services }\end{array}$ & - & L & $\mathrm{H}$ & L & L & - & L \\
\hline $\begin{array}{r}\text { Transport } \\
\text { services }\end{array}$ & - & L & M & L & $\mathrm{L}$ & - & L \\
\hline
\end{tabular}

Indexes range from 1 (lowest ranking) to 5 (highest ranking). Product sectors rank "high" with an index of more than 3.1, medium with an index between 2.7 and 3.1, or low with an index of less than 2.7."n.a"=not applicable. The composite indexes for livestock and beer do not take into account domestic supply conditions and socioeconomic impact due to lack of comparable data

List $1=$ currently exported products, List $2=$ services and non-exported products

$H$ high, $M$ medium, $L$ low

\section{Appendix 3}

Table 10. 


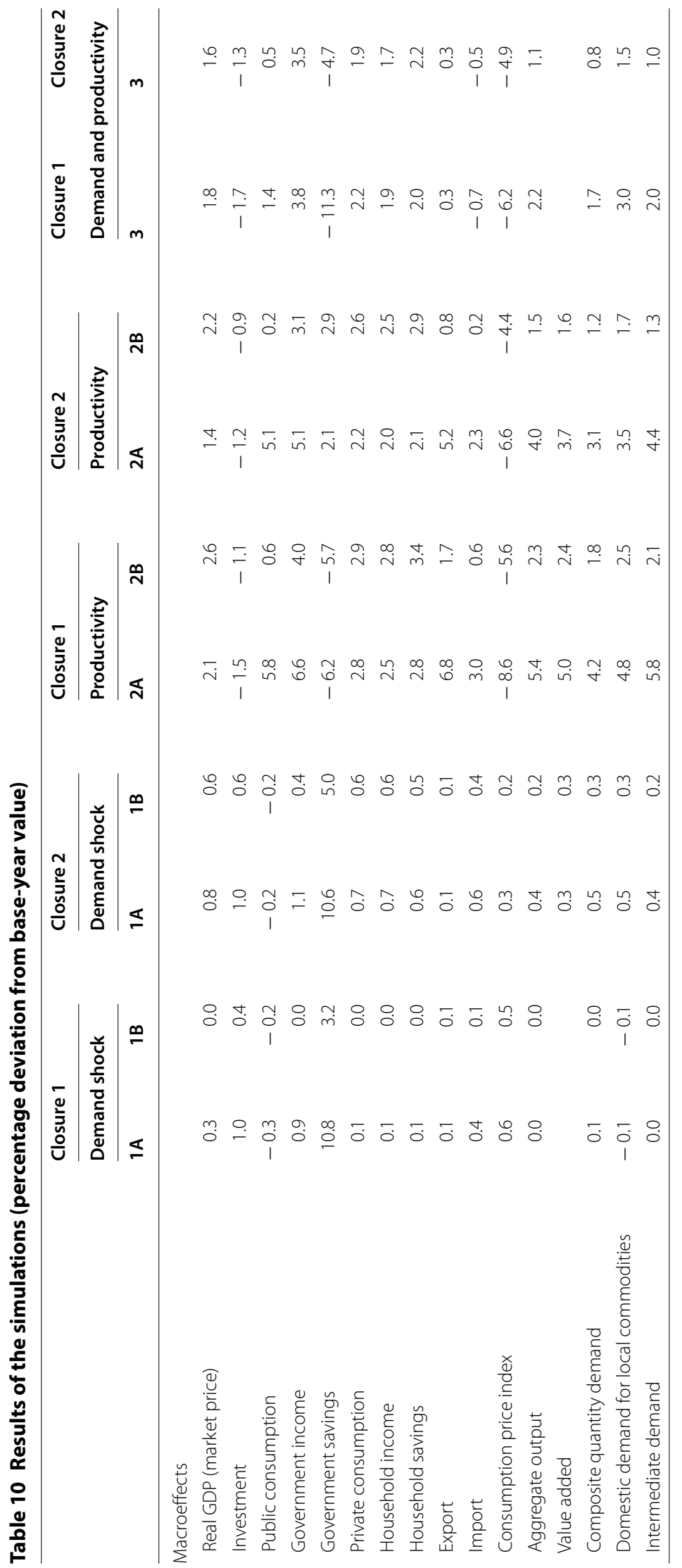




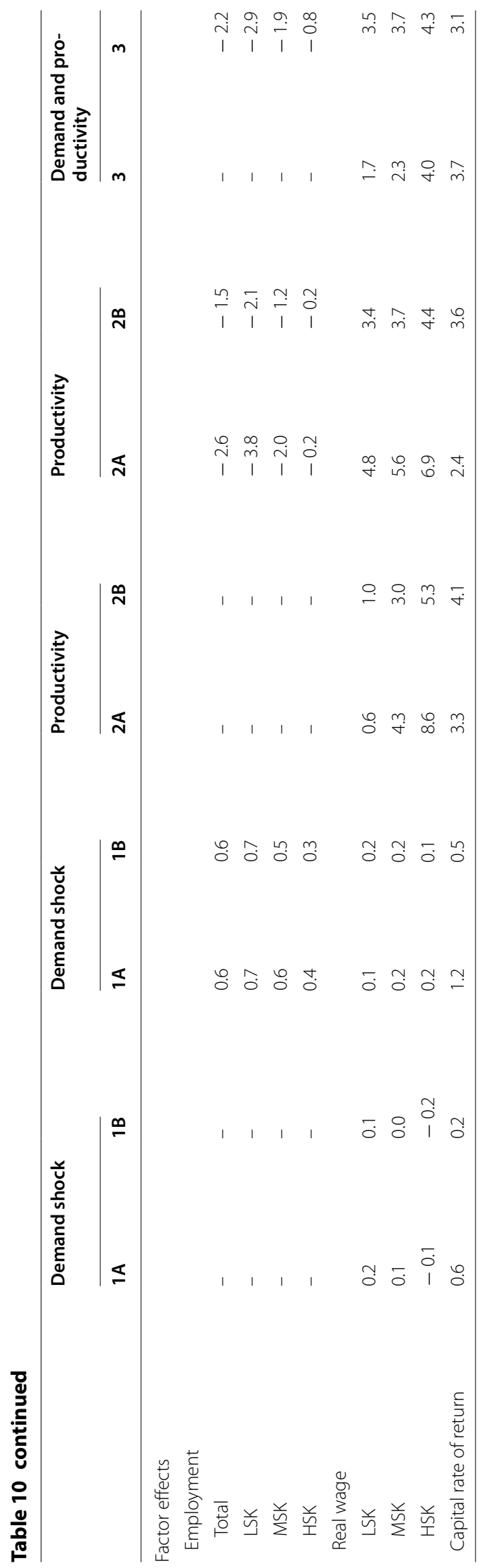




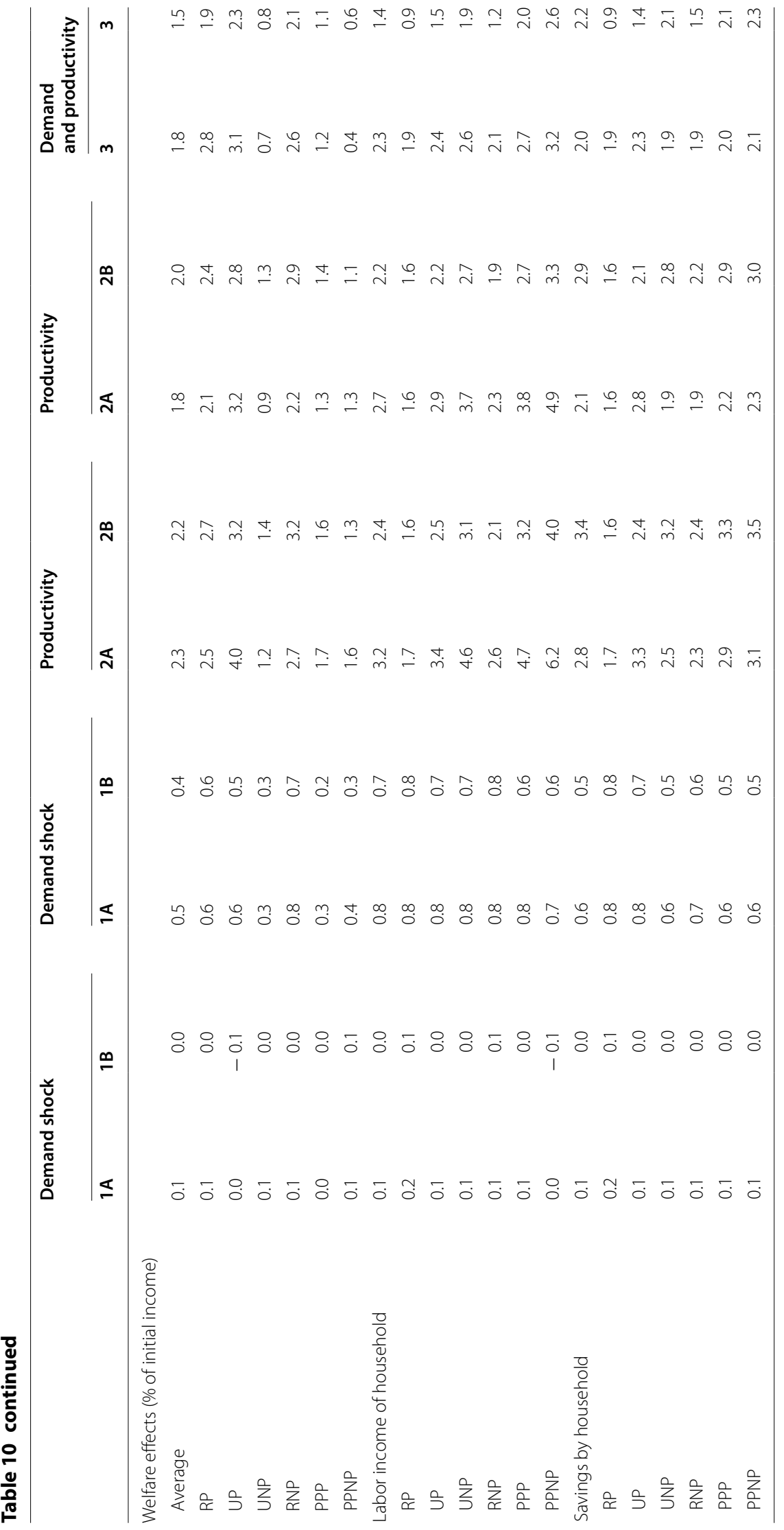




\section{Appendix 4}

Table 11.

Table 11 Sensitivity analysis for Armington and export elasticity (changes from base results)

\begin{tabular}{|c|c|c|c|c|}
\hline & \multicolumn{4}{|c|}{ Demand shock (sim 1A) } \\
\hline & \multicolumn{2}{|c|}{ Armington elasticity } & \multicolumn{2}{|c|}{ Export elasticity } \\
\hline & $20 \%$ increase & $20 \%$ decrease & $20 \%$ increase & $20 \%$ decrease \\
\hline GDP & -0.01 & 0.01 & -0.11 & 0.18 \\
\hline Total investment & -0.01 & 0.01 & -0.15 & 0.25 \\
\hline Public consumption & 0.00 & -0.01 & 0.03 & -0.05 \\
\hline Private consumption & -0.01 & 0.01 & -0.10 & 0.16 \\
\hline Export & 0.00 & 0.00 & 0.00 & 0.00 \\
\hline Import & 0.00 & 0.00 & -0.08 & 0.13 \\
\hline Household welfare & 0.00 & 0.01 & -0.07 & 0.11 \\
\hline $\mathrm{RP}$ & 0.00 & 0.01 & -0.09 & 0.14 \\
\hline UP & 0.00 & 0.01 & -0.08 & 0.13 \\
\hline UNP & 0.00 & 0.00 & -0.05 & 0.08 \\
\hline RNP & -0.01 & 0.01 & -0.11 & 0.18 \\
\hline PPP & 0.00 & 0.00 & -0.04 & 0.06 \\
\hline PPNP & 0.00 & 0.00 & -0.06 & 0.10 \\
\hline
\end{tabular}

\section{Publisher's Note}

Springer Nature remains neutral with regard to jurisdictional claims in published maps and institutional affiliations.

Received: 21 September 2016 Accepted: 23 September 2017

Published online: 27 October 2017

\section{References}

Asian Productivity Organization (2015) Productivity databook 2015. Asian Productivity Organization: Keio University Press Inc, Tokyo

Balassa B (1978) Exports and economic growth: further evidence. J Dev Econ 5(2):181-189

Banse M, Gay SH, McDonald S, M'Barek R, Swinnen JF et al (2007) Competitiveness in the food industry: a CGE modelling approach to assess foreign direct investment in transition countries. In: 104th Seminar, September 5-8, 2007, Budapest, Hungary. European Association of Agricultural Economists

Blanchflower D, Oswald AJ (1994) An introduction to the wage curve. Ame Econ Assoc 9(3):153-167

Burfisher ME (2011) Introduction to computable general equilibrium models. Cambridge University Press, Cambridge

Chan S, Oum S (2011) Impact of garment and textile trade preferences on livelihood in Cambodia (Oxfam America Research Backgrounders Series, 2011)

Chhuor S (2016) Specification of key sectors of Cambodian economy: application of input-output analysis on export potentials. Forum Int Dev Stud 47(7):1-24

Ducaluwe B, Lemelin A, Robichaud V, Maisonnave H (2013) PEP-1-1 the PEP standard single-country, static CGE model. Partnership for Economic Policy-PEP

Ear S (2005) The political economy of pro-poor livestock policy in Cambodia. PPLPI Working Paper No. 26

Ferriol A, Hoang X, Gonzalez A, Hernandez A (2006) Cuba-export promotion, poverty, inequality and growth in the 1990s. Who gains from free trade? Export-led growth, inequality and poverty in Latin America, pp 231-69

Ganuza E, Morley S, Piñeiro V, Robinson S, Vos R (2005) Are export promotion and trade liberalisation good for Latin America's poor? Dev Policy Rev 23(3):385-403

Ha SJ, Swales JK (2012) The export-base model with a supply-side stimulus to the export sector. Ann Reg Sci 49(2):323-353

Hang Chuon N (2011) Cambodian economy: charting the course of a brighter future: a survey of progress, problems, and prospects. Institute of Southeast Asian Studies, Singapore

Heng D, Senh S, Ngim S, Ear S, Em K, Chan T (2014) Impacts of Cambodia's trade liberalization on households's welfare and labor market: a CGE analysis. Partnership for Economic Policy-PEP

Hosoe N, Gasawa K, Hashimoto H (2010) Textbook of computable general equilibrium modeling: programming and simulations. Palgrave Macmillan, London 
Jiménez W (2007) Bolivia-export promotion and its effects on growth, employment and poverty. Who gains from free trade: export-led growth, inequality and poverty in Latin America, p 150

Kobayashi S, Saito K, Tanji H, Huang W, Tada M (2008) Economic structure of Cambodia and strategies for pro-poor growth: results from a computable general equilibrium analysis. Stud Reg Sci 38(1):137-154

Kobayashi S, Tanji H, Saito K, Huang W, Tada M (2009) Industrial structure of Cambodia and the role of agriculture and fishery in its development. Jpn Agric Res Q JARQ 43(4):309-316

Ministry of Agriculture Forestry and Fisheries (2015) Agricultural sector strategic development plan 2014-2018 (strategic development plan). Ministry of Agriculture, Forestry and Fisheries

Ministry of Commerce (2007) Trade related assistance for development and equity. Trade related assistance for development and equity. Ministry of Commerce and United Nations Development Programme, Cambodia

Ministry of Commerce (2014) Cambodia trade integration strategy 2014-2018 (full report). Phnom Penh

National Institute of Statistics (2009) Cambodia Socio-Economic Survey 2009. Ministry of Planning, National Institute of Statistics. Phnom Penh

National Institute of Statistics (2013) Poverty in Cambodia—a new approach. Redefining the poverty line. Ministry of Planning, National Institute of Statistics

National Institute of Statistics (2015) National Account. Gross Domestic Product (GDP) and Per capita GDP 2014

Ram R (1985) Exports and economic growth: some additional evidence. Econ Dev Cult Change 33(2):415-425

Royal Government of Cambodia (2010) Policy paper and the production of paddy production and rice export. Council of Ministries

Royal Government of Cambodia (2015) Cambodia industrial development policy 2015-2025

Sánchez MV, Sauma P (2006) Costa Rica-export-orientation and its effect on growth, inequality and poverty. Who gains from free trade? Export-led growth, inequality and poverty in Latin America, pp 204-30

Tarp H, Tarp JF (2004) On the choice of appropriate development strategy: insights gained from CGE modelling of the Mozambican economy. J Afr Econ 13(3):446-478

Todaro MP, Smith SC (2009) Economic development, 10th edn. Addison-Wesley, Boston

TylerWG (1981) Growth and export expansion in developing countries: some empirical evidence. J Dev Econ $9(1): 121-130$

UN Comtrade (2016) International trade statistics. http://comtrade.un.org/data/

UNCTAD (2012) International trade in goods and services. United Nations Conference on Trade and Development, UnctadStat. Retrieved from May 2013

UNCTAD (2014) International trade in goods and services. United Nations Conference on Trade and Development, UnctadStat. Retrieved from July 2014

UNIDO (2011) Viet Nam industrial competitiveness report (policy advice-industrial policy). UNIDO and Ministry of Industry and Trade of Viet Nam

Vos R (2007) Who gains from free trade: export-led growth, inequality and poverty in Latin America. Routledge

World Bank (2013) Resilience amidst a challenging environment: Cambodia economic update, September 2013 (World Bank Other Operational Studies No. 16632). The World Bank

World Bank (2015) Cambodia economic update : maintaining high growth (No. 95982). The World Bank, pp 1-35

WTO Secretariat (2011) Trade policy review: Cambodia (Policy Review No. No. WT/TPR/S/253). World Trade Organization Yamagata T (2006) The garment industry in Cambodia: its role in poverty reduction through export-orientated development (IDE Discussion Paper. No. 62. 2006.6)

\section{Submit your manuscript to a SpringerOpen ${ }^{\circ}$ journal and benefit from:}

- Convenient online submission

- Rigorous peer review

- Open access: articles freely available online

- High visibility within the field

- Retaining the copyright to your article

Submit your next manuscript at $\boldsymbol{s p r i n g e r o p e n . c o m ~}$ 